\title{
e-Government in Arab Countries: A 6-Staged Roadmap to Develop the Public Sector
}

\author{
Dr. Ali M. Al-Khouri \\ Emirates Identity Authority, PO box 47999, Abu Dhabi, United Arab Emirates \\ E-mail: ali.alkhouri@emiratesid.ae
}

Received: October 11, 2012

Accepted: October 31, 2012

Online Published: February 15, 2013

doi:10.5430/jms.v4n1p80

URL: http://dx.doi.org/10.5430/jms.v4n1p80

\begin{abstract}
Governments the world over are competing with each other to be at a leading position in the arena of e-government. e-Government is seen as a path to modernisation and rendering more efficient and effective public sector services. Recent practices in the field have focused on bringing the government closer to the people. As such, governments worldwide adopted various government-to-citizen (G2C) e-government models in an attempt to improve and provide round the clock availability of all government public services. This article provides a review of the current e-government field with a focus on Arab countries. We present a conceptual six-staged roadmap that illustrates our account of idealisation on how Arab countries should prioritise their e-government short and mid-term efforts. It is a simplified model that represents mega functions that governments need to bear in mind when addressing the changing development needs of the globalised world we live in today. We argue that the stages of the proposed roadmap have the potential to support the development of the public sector and the emergence of the Arab bloc as strong revolutionised citizen-centric governments.
\end{abstract}

Keywords: e-government, Citizen-centricity, Participation, Inclusion, Arab countries

\section{Introduction}

"E-government has been a bipartisan (Note1) effort, today it becomes bicameral (Note2) as well... The era of big government is over we are committed to a smaller, smarter government. New information technologies are tools to help us achieve these goals." Joseph Lieberman.

It comes as a paradox when we attempt to examine the definitions of "government" and "e-government". The commonly recognised definition of government refers to it as being "the act or process of governing; specifically: authoritative direction or control” (Merriam-Webster, 2011). All other definitions expressed in dictionaries and the literature indicate government to be an 'authority', 'enforcer', and 'controller' and so on (MWD, 2011).

On the other hand, e-government is associated with terms such as development, services, access, relationship, etc. As per the United Nations' definition of the concept of e-government, or "digital government", it can be understood as "the employment of the Internet and the world-wide-web for delivering government information and services to the citizens" (United Nations, 2006; AOEMA, 2005).

Therefore, e-government in its essence is about transforming relations with citizens, businesses, and other arms of government with the objective to enhance the overall efficiency and effectiveness of service delivery in the public sector (Hai, 2007; World Bank, 2012). See also Figure 1.

E-government is more to do with enablement and facilitation. E-government facilitates and enables citizen relationships with the government as it takes the process of governance closer to the people. After all, governments are meant to improve life quality and instil a sense of inclusion among its population. Accordingly, e-government enables and facilitates this specific objective through the delivery of services to the citizens and residents at their personal convenience, allowing secure personal transactions with the government with a choice of channels and time, thereby bringing them closer to the government authorities. The potentials are endless.

The aim of this article is to provide an overview of the existing body of knowledge in the field of e-government, and relate it to the discussed topics around citizen-centricity and the delivery of public services. The discussion in the second part of the article focuses more on e-government practices in Arab countries. The major contribution of the article is presented in the form of a six-staged roadmap that illustrates our account of idealisation on how Arab 
countries should prioritise their e-government short and mid-term efforts. The roadmap can be used as a tool for progress monitoring and measurement. The stages of the proposed roadmap are envisaged to have the potential to support the development of the public sector and address the changing needs of the globalised world we live in today.

The article is organised as follows. Section 2 outlines the concept of citizen-centric e-government. It emphasises the need to adopt a strategic planning model to ensure successful e-government implementation. Section 3 presents a number of e-government maturity models to illustrate e-government in the context of its progressive phases. Section 4 emphasises the need to develop information societies to ensure 'inclusive growth' and shifting towards citizen-centric systems. Section 5 presents some recent statistics reported by the United Nations on the development index and evolution of e-government globally. Section 6 sheds light on the e-government maturity in the context of Arab countries. In section 7, the proposed roadmap is presented and its phases are discussed in detail. Finally, some reflections and thoughts are presented in section 8 , where the article is concluded.

\section{Citizen Centric Government}

"Government of the people, by the people, for the people, shall not perish from the earth." Abraham Lincoln (1863)

Citizen-centricity is the crux of governance in modern government terms. It redefines the parameters on which governments interact with their citizens. It also calls governments for more openness, transparency and collaboration. At its most fundamental level, citizen-centricity is a mind shift from an "institution-centred" view of government to a "citizen-centred" view of government (Suthrum \&Phillips, 2003).

Citizen-centricity is not an option for governments in today's vocabulary. In the face of political and economic unrest around the globe, a need arises to redefine the balance between the governing parties and their constituents, in a citizen-centred paradigm that will bring the human factor back into the centre of the equation and will focus on the citizens and their well-being (Rahav, 2012). It is about changing the priorities and opting to put the citizens and their well-being at the heart of government policies and systems (Bhatnagar, 2008; Kearney, 2011; OECD, 2008; Rahav, 2012).

Current research indicates the need for the very effort of stretching the view of the future. It prompts governments to be more practical in how they exploit new opportunities for innovation and transformation to shape their strategic priorities and meet their citizen needs (Di Maio et al., 2005).Numerous models have been developed to support governments in this domain of application. They present conceptual frameworks to transform government infrastructure and enable citizens to become more participative and inclusive in the governance process itself.

However, practices in the field of e-government point out the difficulty of developing systems that can meet today's increasingly changing and complex value landscape (Goldkuhl, 2012).The literature surrounding e-government, in general, denote that governments need to follow a strategic planning model to ensure successful implementation (Homburg, 2008; Lowery, 2001; Otenyo \& Lind, 2011; Sherry et al., 2012). Lack of such strategies is argued to be among the primary causes for existing gaps in coordination and/or communication between various stakeholders and initiatives. It is also attributed to the existence of so-called "islands of automation" and "stovepipes" within and between levels of government (Seifert \& McLoughlin, 2007).

\subsection{Gartner 2020 Government Scenario Planning Tool}

One of the often cited scenario-planning tools in the literature for creating long-term government strategies is depicted in Figure 2. This was developed by the Gartner research group. The model gives a picture of how governments will use and be shaped by technology in 2020. The framework uses two primary driving forces.

The first force is related to the degree of government intervention in the economy, and captures the different attitudes that governments can take vis-à-vis the regulation of economy. The second driving force relates to citizen attitude to privacy and surveillance, and ranges from governments with the freedom to access citizens' personal information to situations in which laws protect citizens' private information.

In the scenario of low government intervention and restrictive regimes, the development of the economy is nearly defunct and remains a status quo. In a case when the government intervenes heavily and citizen participation is highly restrictive, the development is purely a function of the government initiatives. On the other hand, a low participation from the government, combined with a free and highly permissive environment, represents a pure capitalist form of government where the development is determined solely by the free enterprise. An all-round development, well-regulated and participative, is the 'Good Big Brother' approach where the government and citizens 
participate alike in determining the development of the nation.

In practice, we may see all four scenarios to some extent carried out throughout the world, with each country adopting transformation models that better fit their national priorities and policies. In fact, and in the past few years, many countries launched different initiatives for transformation of their governments to increase the inclusiveness of their citizens and residents, all striving to reach out to their citizens and improve life quality (Al-Khouri, 2012; CARICOM, 2009; Nordfors et al., 2006). The essence of these initiatives is to "take the government to the citizen", and move forward from the conventional concept of government offices.

In such transformed operating models, the government is no longer confined to four walls, file cabinets and service counters. It also means that governments can be available on a 24/7 basis, (e.g. over the Internet and through mobile phones, public kiosk machines, digital TV, and call centres, as well as through personal computers). In such operating models, governments attempt to create service-oriented architectures (SOA) (Note 3) and develop a single window platform through which public services are provided.

Prior to digging deeper in the literature to explore governments' maturity, we attempt in the next section to shed light and define the term 'maturity' in the context of e-government and existing developed models to gauge its progress.

\section{3. e-Government Maturity Models}

"It is the framework which changes with each new technology and not just the picture within the frame." Marshall McLuhan

e-Government literature in general classifies its focus areas among three primary groups: (1) citizens, (2) businesses, and (3) the government. The different available models indicate development of relationships between the government and citizen (G2C), government and businesses (G2B), and between government agencies (G2G). See also Figure 3.

\subsection{Forrester e-Government Maturity Continuum}

One of the illustrious transformation models that depicts the evolution of e-government was developed by Forrester Research called e-Government Maturity Continuum. Today, e-government initiatives fall somewhere within the three phases of the framework, namely access era, interaction era, and integration era. See also Figure 4. The framework is used to depict the evolution and transformations that took place over a period of 20 years, starting in 1993, the year in which major e-transformations for citizen-centric governments really began.

The era of access: in this first phase of citizen-centric government initiatives, citizens are able to access government information online. This is the information dissemination and information sharing phase. The idea is to provide real-time information to reach out to the confidence of the people.

The era of interaction: this phase is to allow transactions. In this stage of development, there is some level of transactions taking place between the government and the citizen. Many governments today have adopted Access and Identity Management (IAM) (Note 4) systems to enable and facilitate such transactions.

The era of engagement: this is the last phase of the citizen-centric e-government maturity. It is about enhancing the participation of the citizens in the different aspects of government decision-making in a proactive rather than an impersonal way. Decision-making is no longer the realm of a handful of bureaucrats or a few politicians. Decision-making is heavily influenced by the citizens who are able to cast their voices to shape the policies that govern their lives. At this stage of development, government websites are topically or user-group oriented, enlightened by insights about the constituents they serve. These sites span multiple agencies and multiple levels of government, are more intuitive to use, and reach across multiple channels seamlessly.

Two other famous e-government models are depicted in Figure 5 and Figure 6. Both of the models complement Forrester's e-government maturity model.

\subsection{Layne and Lee's e-government Model}

Layne and Lee (2001) regarded e-government as an evolutionary phenomenon and proposed a four-stage model (see Figure 5):

1) Catalogue stage: This stage delivers some static or basic information through web sites.

2) Transaction stage: This stage extends the capability of catalogue and enables citizens to do some simple online transactions such as filling government forms.

3) Vertical integration stage: This stage initiates the transformation of government services rather than 
automating its existing processes. It focuses on integrating government functions at different levels, such as those of local governments and state governments.

4) Horizontal integration stage: This stage focuses on integrating different functions from separate systems so as to provide users a unified and seamless service.

\subsection{Public Sector Process Rebuilding (PPR) Model}

Andersen and Henriksen's (2006) Public Sector Process Rebuilding (PPR) model is argued to be an extension of the Layne and Lee Model. See Figure 6. They make a case that the PPR model expands the e-government focus to include the front-end of government with a focus on the activity and customer-centric approach rather than the technological capability.

The PPR model consists of four phases:

1) Cultivation phase: shelters horizontal and vertical integration within government, limited use of front-end systems for customer services, and adoption and use of Intranet within government. Organisations in this group are not likely to have digital services and will rarely have instant processing capabilities on the net. Less attention is given to the use of the Internet to increase user frequency, services provided, and/or the quality and speed of services. The downside is that the public institution in this phase will be experienced as inaccessible, have long case processing time, and no accessibility for accessing the processing of requests.

2) Extension Phase: involves extensive use of intranet and adoption of personalised web user interface for customer processes. It may be characterised to involve costly user interfaces, no integration with other systems, expensive maintenance, and fading out of old software and data format. Thus, there are still many manual routines, while the user might find many forms and information where the agency re-directs users to information at other agencies.

3) Maturity Phase: Organisations in this phase mature and abandon the use of the intranet, have transparent processes, and offer personalised self-service web interface for processing customer requests. In this phase, Internet and intranet applications are merged to lower marginal costs for processing the customer requests for services.

4) Revolutionary Phase: This phase is characterised by data mobility across organisations, application mobility across vendors, and ownership to data transferred to customers.

\subsection{Other Models for e-Government}

Several different researchers have developed models to explain the growth of e-government. A short outline about some of these models is provided in Table 1 .

Despite the various models that have been developed to support e-government progress and maturity, governments in practice have gained limited success in the development of a '24-hour Authority'. This is argued to be due to the fact that such initiatives require governments to overcome politics and standardise internal processes and data in order to integrate back-office functions across the public sector (OECD, 2009). Some researchers argue that governments need to redefine the term "access to government" and instead be referred to as "participation". It is also argued that governments need to go beyond superficial initiatives, towards a more radical reengineering of the government processes across its agencies to enable citizen-centric systems and the development of information societies.

\section{Information Society}

"The empires of the future are the empires of the mind." Winston Churchill

Information society is a term associated with the development of a more open, inclusive and sustainable information-based society. See Figure 7. It refers to a society where the creation, distribution, diffusion, use, integration and manipulation of information is a significant economic, political, and cultural activity (Beniger, 1986). The aim of the information society is to gain a competitive advantage, through using information and communication technology (ICT) in a creative and productive way (Feather, 2008; Mattelart, 2003). The knowledge economy is its economic counterpart, whereby wealth is created through the economic exploitation of understanding the different influencing factors and the role of people. People who have the means to partake in this form of society are sometimes called digital citizens. Table 2 provides an elaboration of the three main characteristics that symbolise information societies.

Many countries have followed different transformation models to enable participation and development of citizen-oriented systems (Birch, 2002; Gibson et al., 2005; Hayden et al., 2002; Lowndes et al., 2001; Suh, 2007). 
The following two subsections provide a short overview of relevant government practices to promote citizen participation and development of information societies, namely the Swedish and European experiences.

\subsection{Swedish "Information Society of All" Policy}

In 2000, Sweden set the policy goal to become the first country to be an 'Information Society for All' (European Union, 2012). Since then, the Swedish Government's priority activities have been to enhance public confidence in IT, and help to improve user skills and foster access to IT services. According to the Sweden 24-hour Public Administration Strategy, public information and services should, to the maximum degree, be electronically available 24 hours a day, seven days a week. Another major aim of the strategy was to strengthen democracy by enhancing transparency and citizen participation in the policy and decision-making processes. The strategy for delivery was based on the Swedish decentralised model for Public Administration. Next to small policy ministries, a large number of agencies are responsible for implementing Government policies. The agencies are managed by a system of performance management, where the Government sets targets, allocates resources and appoints managers while following up and evaluating the results.

Sweden remains the most competitive economy as measured by the European Union's (EU) own competition benchmark, the Lisbon criteria (Note 5), followed by Finland, Denmark and the Netherlands, according to the World Economic Forum's Lisbon Review 2010 (World Economic Forum, 2010). Figure 8 depicts a chart that compares Sweden's performance, vis-à-vis the US and East Asia benchmarks. In the figure, Sweden's performance is represented by a blue line, that of the US is in grey, and that of East Asia is in black. Dimensions in which the blue line extends further out than that of the US or East Asia indicate areas where Sweden outperforms these comparators.

\subsection{European "Information Society "Development Framework}

Europe's Information Society policies are brought together under the i2010 Initiative, being the EU framework for addressing the main challenges and developments in the information society and media sectors in the years up to 2010 (European Commission, 2010). The initiative promotes an open and competitive digital economy, research into information and communication technologies, as well as their application to improve social inclusion, public services and quality of life. One of the frameworks that has been developed to trigger debate and discussion in the European Union is depicted in Figure 9.

The origin of the framework goes back to 1995, when the European Union launched an initiative for decentralised cooperation networks between cities and towns cutting across geographical boundaries. The framework seeks to provide complete inclusion of citizens in different stakeholder roles for promoting best practices for the cooperation between the cities/ towns in building information societies. It depicts a multi-dimensional matrix of the stakeholders in the cooperation, namely: (1) government, (2) people, (3) enterprises, and (4) at the decentralised level-the urban environment.

Government focus areas for citizen inclusion and cooperation would be e-government, e-services, e-participation, and online public services. These result in higher transparency and higher efficiencies in service delivery. The efficiencies, productivity and citizen satisfaction are determined by the accessibility to the services by the citizens. The access mechanism itself is determined by the content of the services, the type of applications available for the services and service delivery, and the type of networks enabling this access. Participation of people is enhanced by the knowledge and skills available using different access channels. All the systems need a sustainable management to ensure continual and continuous improvement in the practices to be adopted and followed.

People factors include special interest groups, education and training, health, entertainment and overall community development. Practices attributed to these factors lead to an improvement in the quality of life of the people. Enterprises contribute heavily in the economic development.

SMEs, entrepreneurship, development and support centres for economic growth, and facilitation of e-Commerce are the focus areas of enterprises. The importance of access mechanisms, skills sets, knowledge and sustainable management cannot but be underscored in the development of best practices.

Last but not the least is the urban environment in the cooperation and citizen inclusion framework. The urban environment constitutes the key decentralised governance domain contributing to citizen inclusion, directly leading to higher cooperation between diverse geographic locations.

Having said this, the next section presents some recent statistics reported by the United Nations on the development index and evolution of e-government worldwide, and we shall take a closer look at e-government in Arab countries in the subsequent section. 


\section{United Nations e-Government Assessment}

"There is no discipline in the world so severe as the discipline of experience subjected to the tests of intelligent development and direction." John Dewey (1859-1952)

The United Nations has been tracking the development and evolution of e-governments for the past decade. The UN e-government survey provides a bi-annual assessment of national online services, telecommunication infrastructure and human capital of 192 member states. The UN's e-government maturity model indicates that countries go through primarily four phases of maturity, as depicted in Figure 10.

As per the latest e-government survey in 2012,countries that have advanced to higher growth levels on their e-government projects are the ones with relatively high Web measure/online service index scores. South Korea was rated first for its comprehensive online infrastructure and user involvement level, with a development index of 0.9283, followed closely by the Netherlands with 0.9125 . The rest of the top 10 countries included the UK, USA, Denmark, Norway, France, Sweden, Finland, and Singapore. It is interesting that these countries have very little differences in the composite index that determine their ranking. All the top 10 countries have similarities in how they have implemented e-government. What is more interesting is the list of countries that are identified as the emerging leaders in e-government development. See Figure 11. This is the list wherein each country is distinct in its demographics and political content.

In addition, the list of emerging leaders in e-government development brings another very interesting observation to the fore. The list prominently features three Arab countries, namely UAE, Bahrain and Saudi Arabia. These countries are leading the transformation of governments in the Middle East region. With the increasing use in the internet, social networking, communication technologies combined with a fast-growing educated population, these Arab countries are attempting to create for themselves examples of citizen-centric governments. The next section further elaborates on this.

\section{6. e-Government in the Context of Arab Countries}

"No one ever teaches well who wants to teach, or governs well who wants to govern." Plato

According to the United Nations 2012 Survey, the average e-government development index in the Western Asia continent, that largely comprises Arab nations, is well above the world average, i.e.0.5547 to 0.4882 in 2012 (UNPAN, 2012). See Figure 12. This shows an increase of 6\% over the ratio reported in 2010, as they have shown more growth in the e-government development indexes.

This growth has been enabled by the double digit growth rates in the past few years in the telecommunications industry in West-Asian countries. Telecom companies like ETISALAT (UAE), QTEL (Qatar), BATELCO (Bahrain), STC, Mobily, and Zain (Saudi Arabia), have transformed the telecommunications landscape in the region. They moved from basic telephony providers to provide converged telecommunication services with $3 \mathrm{G}$ and $4 \mathrm{G}$ services on mobile phones, and provide fibre-optic networks across their countries, resulting in faster roll-out and more reliable internet connections.

Figure 13 provides a quick glance at the latest statistics published by Internet World Statistics, which reveal that the internet penetration in the Middle-East is higher than the rest of the world(IWS, 2012). For instance, a higher Internet penetration has enabled a larger number of countries in the region to host government web portals as eminent channels to disseminate information. Furthermore, mobile telecommunications are enabling these governments to deliver services through diverse channels. According to the United Nations (2011), United Arab Emirates, Kuwait, and Estonia have made the same amount of progress in less than two years.

\subsection{Arab Countries and Government Portals}

All Arab bloc countries have strong leadership backing and funded initiatives to modernising existing public service delivery infrastructures. As some Arab countries continue their investments into digital knowledge-based economies, the regional ICT Infrastructure is growing exponentially. Internet penetration and household usage of technology for communication shows a year after year growth in double digit figures.

UAE, Bahrain and Saudi Arabia are considered to be leading the Arab countries in the delivery of online public services.UAE and Bahrain in particular are setting examples in taking a Whole-Government and people-centred development approach. Some of the key initiatives launched in the recent years to support citizen-centric e-government development in these countries are related to:(1) network readiness, (2) infrastructure readiness, (3) service availability, (4) citizen inclusion, and (5) development of a national identity management infrastructure.

The UNPAN e-Government Survey 2012 stated that the: "United Arab Emirates (0.7344) is especially notable as it 
advanced 21 positions to the ranking of 28thglobally and 5th in Asia. The rapid progress of the United Arab Emirates is a best practice case highlighting how effective e-government can help support development. With double the population and three quarters of the GDP per capita, the United Arab Emirates has achieved around the same level of online services as those offered in Norway, a global leader at the 8th position.”

This is validated by the Global Information Technology Report 2011 of the World Economic Forum that provides an index for the overall readiness of the world nations for e-government maturity (Dutta \& Bilbao-Osorio, 2012). The following Figure from this report shows the achievements of the Middle-East nations in their endeavours and quest of e-government.

When we compare this table with the readiness scores sub-indexes, where UAE ranks \#5 on individual readiness and \#3 on Government Readiness, it shows a clear intent of UAE in making itself an example of a successful e-government case study. This intent can be generalised to the region itself. Qatar, Bahrain, Oman, Saudi Arabia, Jordan, Lebanon, Yemen, Egypt, Tunisia, rank among the top 100 countries in e-government development. All development indexes in the Global Information Technology Report 2011 indicate that the regional average is well above the world average. See Figure 16.

Taking a cue from these leaders, the region has shown remarkable advancement in the adoption of citizen-centric e-government programmes. As per the report released by Arab Advisors Group(Al Borgan, 2011), 15 Arab countries host 21 Government portals. This report analysed 19 countries listed alphabetically as Algeria, Bahrain, Egypt, Iraq, Jordan, Kuwait, Lebanon, Libya, Mauritania, Morocco, Oman, Qatar, Palestine, Saudi Arabia, Sudan, Syria, Tunisia, UAE and Yemen.

The most evolved government portals, such as those in the UAE, Bahrain, Qatar, and Saudi Arabia, enable many citizen transactions online. All these portals provide comprehensive information and are following various transformation models to provide transactional services, while the leaders are moving in the direction of whole governments. According to the report, the Arab Advisors Group report 20\% of these portals provide mobile messaging services, while $65 \%$ of the portals already are delivering transactional services. With the widespread usage of mobile phones, there is a clear intention of Arab countries' governments to increase service offerings through more mobile channels.

The available technologies today enable citizen services provided through multiple delivery channels: Internet, mobile phones, help desks/contact centres, hybrid/composite delivery channels, while conventional service counters are the currently used channels. Each channel serves different contact purposes, though not all of them equally effective, as the next sub-section presents. This takes us to a presentation of our proposed model in the next section.

\section{Potential Roadmap of e-Government in Arab Countries}

"To effectively communicate, we must realise that we are all different in the way we perceive the world and use this understanding as a guide to our communication with others." Anthony Robbins

Based on our review of the literature and the information we gathered from our experience in the field of e-government, we developed a six-staged roadmap that provides guidance on how Arab countries should plan and develop their e-government initiatives. The roadmap provides a more focused view of what the e-government journey needs to concentrate on to.

The proposed roadmap consists of six main phases. The first phase in the roadmap is more about transformation and automation of back offices and administrative processes to deliver basic services efficiently to their citizens. The second phase is concerned with the unification of service delivery architectures to enable the delivery of government services through multiple channels, i.e. Internet, kiosk machines, etc. The third phase is concerned with providing digital identities to populations to facilitate the development of innovative e-services. This is followed by integration of service channels in the fourth phase to provide a highly satisfactory user experience. The fifth and sixth phases of the model entail interoperability across the vertical and horizontal dimensions of the government, leading to regional and international interoperability.

The model is simplified to support key decision makers to focus on outcomes rather than the current activities-based and outputs approach that is currently followed in practice. Activities and outputs relate to "what we do."Outcomes refer to "what difference do we make." In the proposed roadmap, the completion of the phase should indicate that the expected outcomes have occurred. The roadmap can be used as a tool for progress monitoring and measurement. We argue that the stages of the proposed roadmap have the potential to support the development of the public sector. The next sub-sections discuss each of the six phases of the model in more detail, using existing literature to clarify and provide examples where needed. 


\subsection{Back Office Process Automation}

Back office tasks are those that do not require direct interaction with citizens and can be performed more efficiently and effectively offsite. Major reforms took place in the public sector administration in Arab countries in the past 10 years, and more intensively after the global financial crisis. Arab Governments have shown interest and been striving to improve the efficiency and effectiveness of their operations. Central to these reforms has been the establishment of governance practices, including the application of modern technology in delivering information and transaction services to citizens.

Arab Governments have shifted many of the front desk processes in the public sector to be performed by back office operators. They have succeeded to some degree in introducing systems that automate and streamline back office business processes under the umbrella of e-government. However, existing back office operations in Arab countries are very much paper and labour-intensive. Thus, many of the government services still require citizens to visit different departments to access public services, even after the introduction of ICTs, as systems are not interconnected (UNDP, 2007).

The primary reason for this is that Arab countries have focused on process automation rather than conducing a process re-engineering (transformation) prior to automation, i.e. same old procedures put in automated forms. This is considered, in our opinion, to be one of the factors that has hindered e-government progress in Arab countries.

Arab governments need to pay more attention to re-engineering initiatives that take a holistic view of the government as a whole and attempt to create a business case for enhanced cost-to-income ratios, increase operational efficiencies, and gain a greater share of the citizens' satisfaction. The same initiatives need to focus on capturing the undocumented knowledge and standardising repeatable processes across government agencies. This should be the first step in pursuit of operational excellence in the public sector. Such initiatives have the potential to enable harmonisation of customer service levels across government agencies, and bringing significant productivity gains, i.e. reduced processing cycle times and improved quality, visibility and transparency of operations.

\subsection{Single Window System to Deliver Public Services}

In a single window system, access to public services is realised through a governmental portal. Most governments in Arab countries have their own national governmental portals. However, despite the efforts and investments made to date, those portals are still in the first and second phases of Layne and Lee's (2001) e-government evolution model (Al-Khouri \& Bal, 2008).Based on our knowledge and interaction with e-government initiatives in the Arab world, we tend to argue that the majority of e-government in Arab countries fail and are stuck in the Access phase of Forrester's maturity model. The other evolved Arab countries in e-government are still in the early steps of the interaction phase.

Success in the delivery of public services depends on numerous factors such as flexibility, accessibility, completeness, easiness, security, etc. A single window system that delivers public services and combines all these factors is among the hot topics in government business today. A single window system or 'one stop window shop' concept refers to the integration of public services from a customer of public services' point of view (Wimmer \& Tambouris, 2002). It allows citizens, businesses and other authorities to have 24-hour access to public services from their home, their offices or even on the move using different access media and devices (ibid.).

A significant trait of a single window system is accessibility, which should enable multiple delivery and interaction channels between citizens and the government. Each of the channels may have its uniqueness and its value added in terms of speed, convenience, and in the way it allows citizens to interact and communicate with the government at designated offices, call centres, or through the Internet, mobile devices, cable TV, etc.

A single window system should allow citizens to have 24-hour access to electronic public services from their homes, libraries, schools, shopping malls or even on the move. Figure 18 provides an overview of the various service channels and their applicability and general effectiveness.

Implementing a strategic plan is always a big challenge and a channel strategy is no exception. This is to say that developing a single window system with multiple delivery channels is a complex and multifaceted domain that is not only associated with technological systems but also organisational, legal and social. Providing services in a citizen-oriented view calls for a new, service-oriented design approach (eEurope, 2002).

For an effective citizen-oriented system, we suggest that service providers in the public sector need to adopt hybrid models that enable citizens to interact with the government using multiple channels. Such multi-channel strategy can address objectives of today's public bodies akin to improving the services provided to the user community and/or 
reducing the costs of providing its services (European Commission, 2004).

In hybrid service models, a communication established through one channel should be available from another channel to provide a seamless user experience. This also allows unified modes of service delivery and service fulfilment to provide enhanced service options for the citizens to choose from.

As the services and delivery channels mature, service delivery capability maturity sets in. As service maturity improves, responsibility and accountability in public service become apparent and the government as a whole can stand to guarantee availability of the delivered services. Service level agreements could be openly published and efficiency of public service measurements publicly available.

A government that can guarantee such service level agreements for its citizens would then be a true citizen-inclusive e-government. But the journey has only just begun- there is a long way to go before citizens are able to interact seamlessly and derive the true benefits of e-government. This seamless experience is possible when a unified identity is established for the citizen, as the next section elaborates.

\subsection{Digital Identities Profiles}

In order to build trust in e-government, we have emphasised in our previous articles on the need to develop digital identity management systems to provide services such as user identification, authentication, and authorisation in an e-government environment (Al-Khouri, 2012). A digital identity management system is based on (1) a schema for representing digital identities (a database subset, for example, that includes name, last name, date of birth, photo, certificate, serial number, etc.) and (2) authentication mechanisms and protocols that entities use to demonstrate they are the owners of a given digital identity (Windley, 2004). Accordingly, the purpose of a digital identity is to tie a particular transaction or a set of data in an information system to an identifiable individual. With the help of a digital identity, a user can be identified and authorised to use a given resource or service (Corradini et al., 2007).

Identities and identity management are of primary importance for governments as they encompass the identification of citizens and their interactions with public services and government institutions (Mont, 2002). Trusted, secure and accountable identity management solutions are key e-government enablers. Current systems used in e-government schemes generally do not address security needs, as they merely rely on fixed information to authenticate a user whose full identity might be revealed.

Many of the Arab countries have initiated advanced national identity management programmes in the last 10 years, e.g. UAE, Oman, Bahrain, Qatar, Saudi Arabia. These initiatives are based on sophisticated technologies such as biometrics, smart cards and a public key infrastructure that, altogether, provide strong government-issued digital identity profiles for their population.

The digital identities in these countries are packaged in different ways based on the individual national policies. For instance, the national identity card of UAE has rolled fingerprint biometrics, digital certificate and a unique identity number that, in total, constitute the digital identity of the cardholder. Other countries have either one or two of these three parameters with different biometric systems, e.g. iris recognition, facial recognition. The impact of the digital identity profile is on the types of services that can be delivered across different channels.

A trusted, secure and accountable identity management system is a principal facilitator for governments to go up the ladder of e-government maturity. Governments need to understand that identity management is about the management of digital identity and profile information. Governments in the phase need to deploy and promote widespread adoption of an open, flexible, policy-driven, context-aware identity management system that scales across multiple-service contexts; it needs to be integrated with other management aspects including authentication, authorisation, provisioning and data consolidation, along with related trust, security and privacy aspects (Corradini et al., 2007).

\subsection{Integrated e-Services: e-Government and Service Delivery Frameworks}

Multi-channel integration opens up opportunities to move more processes to self-service channels, reducing costs for the banks and increasing access for citizens. In fact, it presents opportunities for government agencies to standardise and automate business processes that contribute unequivocal value.

Integration, as a more abstract concept, could mean to bring some parts together and make them a coherent whole (Goldkuhl, 2008). Such integration could mean that different information systems are integrated into one system. Integration could, however, also mean that the parts remain as separate entities but that they work together in a well-functioning manner as federated systems (ibid).

Many countries worldwide have struggled with e-government and service delivery frameworks. The subject of the 
right enterprise architecture models has been controversial and debatable. In Arab countries, deployed customer relationship models vary from one country to another in terms of access channels, execution, delivery and customer service criteria. UAE, for example, has developed the eServices Delivery Excellence Model that provides mandatory standards and optional best practices that guide government agencies in Dubai on how to develop and deliver eServices, as well as how to evolve toward a culture of e-government excellence (DEG, 2009).

This phase in our model focuses on areas such as usability and ease of service delivery process, performance, reliability and connectivity and, most importantly, security. While end-users may not encounter these issues directly, they still contribute to the e-service access, delivery and execution and, together, will provide a means of seamless and user-centred service delivery.

Rabaiah \& Vandijck (2009) proposed a comprehensive e-government framework that defines some strategic building blocks to develop e-government and citizen services. The framework, which has been modularised for flexibility, extensibilities and customisability, incorporates very important components of the front office and back office views. See Figure 19.The entire e-government development is based on a strong ICT approach with interconnected government departments and integrated databases offering single window services to the citizens over multiple channels. This is the essence of e-government.

Rabaiah \& Vandijck's (2009) framework interestingly suggests channel integration for a unified service delivery mechanism. E-government initiatives are primarily focused on the citizen and the enablement of the inclusion of the citizen in the government. At the basic level, one would look at providing information over multiple channels that citizens can choose from to interact with the government. With the evolution of the e-government practices and enhanced back-end integration, maturity in delivery of services over unified channels is achieved. As the citizen satisfaction with the services increases, the same channels could mature into popular and transparent decision-making tools for the citizen voice to be heard through the government, thus shaping the policies of the nation.

Federated identity management plays a key role in this phase. Federated identity management (FIM) refers to an infrastructure that consists of technologies, standards and use-cases which serve to enable the portability of identity information across otherwise autonomous security domains. FIM enables users of one domain to securely access data or systems of another domain seamlessly, and without the need for completely redundant user administration (Bertino \& Takahashi, 2010).

Use of FIM can increase security, lower risks, and reduce cost by eliminating the need to deploy multiple identity management systems. It can also drastically improve the end-user experience by eliminating the need for account registration through automatic "federated provisioning", i.e. authenticate the user once and use the same identity information across multiple systems (also referred to as single sign-on).

\subsection{Government Interoperable Systems: An Interoperability Framework}

As the Arab governments march ahead in their quest for an evolved e-government, they need to keep an eye on the evolving integration models. This is critical for government agencies that play a role in the development of public services. Interoperability of the electronic services and the interoperability in communication protocols, unified identity management, and business process integration form some of the various parameters of interoperability.

Interoperability, as defined by the United Nations Development Programme, refers to "the creation of systems that facilitate better decision making, better coordination of government agency programmes and services in order to provide enhanced services to citizens and businesses, the foundation of a citizen centric society, and the one-stop delivery of services through a variety of channels" (UNDP, 2007).

It is imperative that, within each country, the e-initiatives are able to benefit the entire rather than a dispersed narrow section served by isolated departments. In the UAE, for example, the seven emirates launched their own e-services and service channels. Each of the emirates provides its own e-government portal that enables the local population to interact with the governments. Until recently, these initiatives were confined to each of the Emirates.

Standardisation and interoperability is being sought now and work is afoot to ensure seamless integration of the services across the seven Emirates. The UAE's government identity management infrastructure is envisaged to play a key role to standardise how people will access information and be authenticated across the Emirates. The application of a federated identity management system, combined with the public key infrastructure and the national population certification authority (CA) (Note 6), is expected to bring in a paradigm shift in the citizen experience in how they are introduced to e-services. 
Identity management integration is a major contributor to interoperability. A complete interoperability model would have to be based on more considerations to data exchange, information exchange, communication protocols, networks interoperability, and process integration.

The definition of interoperability, put forth by the European Commission's European Interoperability Framework, is seen as very relevant in the Arab bloc. It defines interoperability, within the context of European public service delivery, as "the ability of disparate and diverse organisations to interact towards mutually beneficial and agreed common goals, involving the sharing of information and knowledge between the organisations, through the business processes they support, by means of the exchange of data between their respective ICT systems" (European Union,2011).

Seen in this context of interoperability, and keeping the regional sensitivities and socio-political environment development of Intra-Government and Inter-Government interoperability, is seen more as a need than a mere idea of formation.

However, repeated failures to build working systems show that the task is not only difficult but also poorly understood (Navakouski \& Louis, 2012). Navakouski \& Louis (2012) proposed a framework for understanding interoperability in the e-government context and how to address its requirements and challenges from policy making and system development perspectives. See also Figure 20.

The proposed framework has three primary components: technical, semantic, and organisational. These components are governed by legal, political and socio-cultural factors. At the basic level, interoperability should enable data exchange at the technical level, where systems can exchange data securely. These are essentially database integration, web services, SOA protocols, etc., and depend on network connectivity.

At the next level is exchange of information that enables the content exchange in terms of the meaning of the information. At the third level is the business process integration and agreements on processes in different departments to basically agree with and complement each other. This handles the policies and procedures to ensure that there is no cross-dependency or counter-dependencies. The last thing one would want is two government departments working at loggerheads! This counter-dependency is even more relevant in the Arab bloc of countries that share common borders and common cultural sensitivities.

\subsection{International Interoperability}

Interoperability issues also have an international facet, including different levels of conformance and implementation strategies across countries and regions. Even in a world where the international community cooperates to minimise interoperability problems, parallel ongoing development activities in Asia, Europe, and America will inevitably lead to interoperability issues (Gallagher \& Jeffrey, 2006).

The e-Government Interoperability Framework (e-GIF) introduced by the UK government in 2004 covers communication, not just within government, but the exchange of information between government systems and citizens, intermediaries, businesses (worldwide), and other governments (UK/EC, UK/US, etc.) (OeE). The framework covers technical policies and specifications for achieving interoperability and ICT systems coherence across the public sector. It defines the essential prerequisites for joined-up and web-enabled government and aims to reduce the costs and risk of operating information technology systems, while keeping the public sector in step with the global internet revolution.

Another framework is the European Interoperability Framework (EIF) adopted by the European Union (European Commission, 2010). It provides a basis by which to move on effectively with the implementation and realisation of interoperability in the area of e-government services and move on to more and better public services in Europe.

The Framework sets a number of general principles, which should be considered for any e-government service to be set up at a pan-European level: accessibility, multilingualism, security, privacy, subsidiarity, use of open standards, assessing the benefits of Open Source Software, and use of multilateral (or 'many-to-many') solutions. Based on these principles, the EIF addresses five distinct interoperability levels that need to be considered for the development of cross-border and pan-European e-government services (See Figure 21):

- Political interoperability: is concerned with political support and sponsorship to provide better, more user-focused public services and cross-border interoperability efforts to facilitate cooperation among public administrations.

- Legal interoperability: contributes to the provision of a European legal framework that is related to the exchange and protection of data between member states to provide European public services, the validity 
across borders.

- Organisational interoperability: is concerned with the definition of business goals and processes by different administrations working together to deliver a service.

- Semantic interoperability: refers to the possibility for the precise meaning of exchanged information to be understandable by any application not initially developed for this purpose.

- Technical interoperability: covering the technical issues of linking-up computer systems, including key areas such as open interfaces, middleware, accessibility and security services.

Arab governments need to agree on and follow similar frameworks that should facilitate business across national borders. To meet this objective, Arab governments need to design and maintain their own version of e-GIF that can take into consideration cultural, political and other technical contexts. This should ensure that the adopted e-GIF provides Arab government agencies with a supportive framework that is aligned with the international environment of interoperability policies, standards and guidelines. We emphasise that the Arab e-GIF framework needs to be based on the use and adoption of internationally accepted standards, as such bespoke policies, standards and guidelines will only be developed where deemed strictly necessary. Wherever feasible and relevant, the e-GIF should:

- utilise existing information and technology policies, standards and guidelines to enable the seamless flow of information across government/public service organisations;

- mirror established and open international standards for interoperability;

- draw upon the interoperability framework developed in other jurisdictions, e.g. the EIF and UK e-GIF;

- $\quad$ set practical standards using stable and well-supported products;

- provide support, guidance and toolkits to enable the standards to be met; and

- provide a long-term strategy that is able to accommodate and adapt.

Global interoperability requires the architecture to support operations between different systems that represent and handle digital identity using different formats and schemas and have no previously-established trust relation (Safelayer Labs, 2012).

Arab countries need to pay attention to interoperability of identity management systems between governments that may be seen as a desirable requirement to prevent fraud and theft, e.g. in the case of a biometric passport which needs to be readable and holders' identity verified at the departure and arrival port of two different international airports (EU JRC, 2005). Interoperability needs to evolve towards higher levels of flexibility and capability to react to global changes. Their functionalities need to be orchestrated with other management aspects, including trust, privacy and security management.

GCC countries (Note 7) have initiated multiple projects related to advanced applications development of their electronic identity (e-Identity) schemes. GCC countries are currently working on developing a unified e-identity infrastructure to enable identification and authentication of GCC citizens at any of the GCC member states (Al-Khouri \& Bachlaghem, 2011). This is argued to raise serious interoperability issues due to the different and complex infrastructure setups at each member state and would likely challenge such a project (ibid).

All in all, there is a growing recognition worldwide that interoperability is essential to the Information Society (Miller, 2004) and to deliver on the promise of government transformation (Pardo \&Burke, 2008). In an increasingly interdependent global economy, the task of developing interoperability standards for practical applications becomes more complicated, but the rewards become even greater(Miller, 2004). Interoperability and the use of data for management, decision-making, and governance can be powerful forces for development and prosperity across the globe, or they can effectively divide countries, people, and markets into independent and separate groups (ibid).

Interoperability within a country or between Arab countries requires leadership and authority. Regardless of context, local, national, or international interoperability is an important foundational capability for government transformation (Pardo \&Burke, 2008).A more interoperable government system can change the nature of democracy and citizen participation, and provide systems for services improvement, efficient and effective operationsof government, and the development of stable and vital economies (ibid).

\section{Conclusion}

\section{“The most important thing in communication is to hear what isn't being said.” Peter F. Drucker}


Our research presents some useful implications for both research and practice. With regard to research, we have attempted to provide a focused view of the existing literature surrounding e-government and its potential role in improving public sector performance. It also provided some deeper insights to support understanding of related practices in the Arab world.

With regard to practice, our study offers implications for policy makers and public administrators. The proposed roadmap provides governments with six primary stages as possible determinants of e-government progress in their contexts. Accordingly, more attention may be placed on such noted stages to enhance e-government maturity in their settings.

By and large, the presented roadmap in this article was an attempt to provide a high level conceptual set of steps for Arab governments to focus on in order to progress in the field of e-government and transform the public sector. The roadmap promotes business process transformation at government back offices rather than existing blind automation efforts. It also emphasises the provisioning of integrated e-services through a single, one-stop window and pays heed to interoperability, both at government and regional levels. The proposed roadmap can help Arab governments to move in the direction of building citizen-centric systems and looks at development priorities from the eyes of the citizens.

Arab governments need to shake their existing knowledge base about e-government. The existing body of knowledge is, to some extent, perplexing where government practices have been shaped and influenced by mere IT suppliers or private sector consultancy firms. Governments need to create the 'intent' to accept change; the change in mindset that citizens must be in the heart of any development plan. The change should be from within the government and must reflect their practices and deployed systems.

The citizen-centric government should seek to provide higher levels of customer satisfaction. Governments need to treat themselves as service delivery organisations, where citizens become customers and are integrated in the delivery system design and development. Such delivery systems need to be designed to provide citizens with multiple and integrated interfaces and channels to transact with the government through a single window system.

From a technical perspective, providing integrated services can only be realised if all public authorities are interconnected and their systems are interoperable. Governments need to recognise that cost reduction and quality improvement can only be achieved when processes are redesigned, databases integrated and, perhaps, certain tasks centralised (Kubicek \& Cimander, 2005). In many of these cases, IT systems have to be redesigned as well, and systems which once stood alone have to be integrated and be able to exchange data with other systems (ibid.). They have to become interoperable.

Arab governments need to have the ability to monitor e-government progress and evolution in their countries. This should support sustaining the momentum of complex, cross-departmental projects, promoting good governance, and ensuring that the change management challenges of government level projects are overcome successfully. The proposed roadmap was developed for this specific need.

In short, Arab public administration needs a radical transformation. The modernisation of public administration is a long-term task, requiring tenacity and innovative thinking. Some Arab countries are now embarking on a new phase in the development of e-government. Arab governments need to pay more attention to the overall e-government concept in modernising their nations and building stronger economies that can speak the language of the future.

\section{References}

Al Borgan, Z. (2011). Electronic Government Initiatives in the Arab World 2011. Arab Advisors Group. [Online] Available: http://www.arabadvisors.com (July 12, 2012)

Al-Khouri, A.M., \& Bachlaghem, M. (2011). Towards Federated Identity Management Across GCC: A Solution’s Framework. Global Journal of Strategies \& Governance, 4(1), 30-49.

Al-Khouri, A.M. (2012). PKI in Government Digital Identity Management Systems. European Journal of ePractice, 14, 4-21.

Andersen, K. V., \& Henriksen, H. Z. (2006). EGovernment maturity models: Extension of the Layne and Lee model. Government Information Quarterly, 23(2), 236-248.

Baier, T., Zirpins, C., \& Lamersdorf, W. (2003). Digital identity: How to be someone on the net. In Isaias, P. and Reis, A., (Eds.), Proceedings of the IADIS International Conference of e-Society, (2, pp. 815-820). Lisbon, Portugal: IADIS Press. 
Baum, C., \& Maio, A.D. (2000). Gartner's Four Phases of EGovernment Model. Stamford: Gartner Group Inc.

Beniger, J.R. (1986). The Control Revolution: Technological and Economic Origins of the Information Society. Cambridge, Mass.: Harvard University Press.

Bertino, E., \& Takahashi, K. (2010). Identity Management: Concepts, Technologies, and Systems. Boston, MA: Artech House Publishers.

Bhatnagar, S. (2008). Building Trust through E-Government: Leadership and Managerial Issues. United Nations Public Administration [Online] Available: http://unpan1.un.org/intradoc/groups/public/documents/unpan/unpan025871.pdf (July 1, 2012)

Birch, D. (2002). Public Participation in Local Government: A survey of local authorities. Local and Regional Government Research Unit, Office of the Deputy Prime Minister: London. [Online] Available: http://www.communities.gov.uk/documents/localgovernment/pdf/145623.pdf (July 1, 2012)

Bukhsh, F.A., \& Weigand, H. (2011). E-Government controls in service-oriented auditing perspective: Beyond Single Window. In Overbeek, S.; Tan Y.-H. \& Zomer, G. (Eds.), Proceedings of the 1st Workshop on IT Innovations Enabling Seamless and Secure Supply Chains, In conjunction with the EGOV 2011 (pp. 76-90). Delft: CEUR.

Camp, J. (2003). Identity in Digital Government: A report of the 2003 Civic Scenario Workshop. National Science Foundation \&The Kennedy School of Government. [Online] Available: http://www.ljean.com/files/identity.pdf (July 15, 2012)

CARICOM. (2009). Improved Government, Better Service: Draft 2010 - 2014 CARICOM eGovernment Strategy. Caribbean Centre for Development Administration. CARICAD. [Online] Available: http://www.gov.gd/egov/docs/ict_egov/draft_2010_2014_CARICOM_egovernment_strategy.pdf (July 15, 2012)

Chandler, S., \& Emanuel, S. (2002). Transformation Not Automation. In Proceedings of 2nd European Conference on Egovernment. St Catherine’s College Oxford, UK, pp. 91-102.

Chen, H. (2002). Digital Government: Technologies and Practices. Decision Support Systems, 34, 223-227.

Clarke, R. (2001). Person location and person tracking: Technologies, risks and policy implications. Information Technology \& People, 14(2), 206.

Corradini, F. Paganelli, E., \& Polzonetti, A. (2007). The e-Government digital credentials. International Journal of Electronic Governance, 1(1), 17-37.

DEG. (2009). eServices Delivery Excellence Model. Dubai eGovernment Department [Online] Available: http://www.deg.gov.ae/SiteCollectionDocuments/Content/English/eServices Delivery Excellence Model.pdf (July 15, 2012)

Deloitte and Touche. (2001). The Citizen as Customer. CMA Management, 74, 10, 58.

Di Maio, A., Kreizman, G., Harris, R.G. Rust, B., \& Sood, R. (2005). Government in 2020: Taking the Long View. Garnter Research Group. [Online] Available: http://www.gartner.com/resources/136400/13646-6/government_in_2020_taking_th_136466.pdf (July 15, 2012)

Dutta, S., \& Bilbao-Osorio, B. (eds.) (2012). The Global Information Technology Report 2012: Living in a Hyperconnected World. [Online] Available: http://www3.weforum.org/docs/Global_IT_Report_2012.pdf (July 15, 2012)

eEurope. (2002). Web-based Survey on Electronic Public Services. [Online] Available: http://europa.eu.int/informa-tion_society/eeurope/egovconf/documents/pdf/eeurope.pdf (July 15, 2012)

EU JRC. (2005). Biometrics at the frontiers: Assessing the impact on society. European Commission Joint Research Centre, Seville, Spain, Tech. Rep. EUR 21585 EN.

European Commission. (2004). Multi-channel delivery of eGovernment services. [Online] Available: http://www.cisco.com/web/DE/pdfs/publicsector/ida_07_04.pdf (July 15, 2012)

European Commission. (2004). The European Interoperability Framewor", v.1.0: final EIF Version 1.0. [Online] Available: http://ec.europa.eu/isa/documents/isa_annex_ii_eif_en.pdf (July 15, 2012)

European Commission. (2010). Communication Towards interoperability for European public services (COM(2010) 744). [Online] Available: http://eur-lex.europa.eu/LexUriServ/LexUriServ.do?uri=COM:2010:-0744:FIN:EN:PDF (July 15, 2012) 
European Commission. (2010). i2010 - A European Information Society for growth and employment. [Online] Available: http://ec.europa.eu/information_society/eeurope/i2010/index_en.htm (July 15, 2012)

European Communities. (2004). European Interoperability Framework for Pan-European eGovernment Services. Luxembourg: Office for Official Publications of the European Communities. [Online] Available: http://europa.eu.int/idabc (July 15, 2012)

European Union. (2011). European Interoperability Framework (EIF): Towards Interoperability for European Public Services. Luxembourg: Publications Office of the European Union. [Online] Available: http://ec.europa.eu/isa/documents/eif_brochure_2011.pdf (July 15, 2012)

European Union. (2012). eGovernment in Sweden. ePractice. [Online] Available: http://www.epractice.eu/fil-es/eGovernmentSweden.pdf (15 July 2012)

Feather, J.P. (2008). The Information Society: A Study of Continuity and Change. London: Facet Publishing.

Fernandez, A., \& Oviedo, E. (ed) (2011). e-Health in Latin America and the Caribbean: progress and challenges. United Nations [Online] Available: http://www.eclac.org/publicaciones/xml/0/44450/2011-205-eHealth_in_LAC_WEB.pdf (July 15, 2012)

Gallagher, M.D., \& Jeffrey, W.A. (2006). Technical and Economic Assessment of Internet Protocol Version 6 (IPV6). National Telecommunications and Information Administration \& National Institute of Standards and Technology. [Online] Available: http://www.ntia.doc.gov/legacy/ntiahome/ntiageneral/ipv6/final/IPv6final.pdf (July 15, 2012)

Gibson, P.D., Lacy, D.P., \& Dougherty, M.J. (2005). Improving Performance and Accountability in Local Government with Citizen Participation. The Innovation Journal: The Public Sector Innovation Journal, 10(1), 1-12. [Online] Available: http://www.innovation.cc/volumes-issues/gibson1.pdf (July 9, 2012)

Goldkuhl, G. (2008). The challenges of Interoperability in E-government: Towards a conceptual refinement. pre-ICIS 2008 SIG eGovernment Workshop, Paris. [Online] Available: http://www.vits.org/publikationer/dokument/664.pdf (July 6, 2012)

Goldkuhl, G. (2012). From policy to design and effects: A framework for e-government research. 9th Scandinavian Workshop on E-Government, February 9-10, 2012, Copenhagen. [Online] Available: http://www.vits.org/publikationer/dokument/766.pdf (July 6, 2012)

Hai, J.C. (2007). Fundamental of Development Administration. Selangor: Scholar Press.

Hayden, C.T., Sanford, A.L., McGivern, D.O., Cohen, S.B., Dawson, J.C., Bennett, R.M., ... CoreS-Vazquez, L.A. (2002). Participation in Government. The University of the State of New York. [Online] Available: www.p12.nysed.gov/ciai/socst/documents/partgov.pdf (July 2, 2012)

Hilty, L.M. (2011). Localisation technologies Project, University of Zurich. [Online] Available: http://www.ta-swiss.ch/?uid=146 Accessed (July 8, 2012)

Homburg, V. (2008). Understanding E-Government: Information Systems in Public Administration. London: Routledge.

Howard, M. (2001). EGovernment across the Globe: How will "e" Change Government? Government Finance Review, 17(4), 6-9.

Ifinedo, P., \& Singh, M. (2011). Determinants of eGovernment Maturity in the Transition. Economies of Central and Eastern Europe. Electronic Journal of e-Government, 9(2), 166 -182.

Kearney, A.T. (2011). How to Become a Citizen Centric Government. [Online] Available: http://www.atkearney.com/images/global/pdf/Citizen-Centric_Government.pdf (July 3, 2012)

Klewes, J., \& Wreschniok, R. (eds.) (2009). Reputation Capital: Building and Maintaining Trust in the 21st Century. Heidelberg: Springer.

Kubicek, H., \& Cimander, R. (2005). Interoperability in eGovernment A Survey on Information Needs of Different EU Stakeholders. [Online] Available: http://www.ifib.de/publikationsdateien/IOP_in_eGov_-_Survey_on_Information_Needs.pdf (July 15, 2012)

Layne, K., \& Lee, J. (2001). Developing Fully Functional eGovernment: A Four Stage Model. Government Information Quarterly, 18(2), 122-136.

Lee, T., Hon, C.T., \& Cheung, D. (2009). XML Schema Design and Management for e-Government Data 
Interoperability. Electronic Journal of e-Government, 7(4), 381-390.

Lenihan, D.G. (2008). Realigning Governance: From E-Government to E-Democracy. In Anttiroiko, A. (Ed.), Electronic Government: Concepts, Methodologies, Tools, and Applications (pp. 3389-3422). Hershey PA: IGI Global.

Lowery, L.M. (2001). Developing a Successful E-Government Strategy. United Nations Public. Administration Network. [Online] Available: http://unpan1.un.org/intradoc/groups/public/documents/APCITY/UNPAN000300.pdf (July 15, 2012)

Lowndes, V., Pratchett, L., \& Stoker, G. (2001). Trends in public participation: part 1 - local government perspectives. Public Administration, 79(1), 205-222.

Lozano, L., Hilbert, M., Takahashi, T., Legale, E., \&Virapatirin, M. (2003). Basic Document: Network 13 Towns \& The Information Society. [Online] Available: http://centrourbal.com/sicat2/documentos/07_2009723448_R13P3-04A-db1-eng.pdf (July 15, 2012)

Mattelart, A. (2003). The Information Society: An Introduction. London: Sage Publications Ltd.

Merriam-Webster Dictionary. (2011). [Online] Available: http://www.merriam-webster.com/dictionary/government (July 15, 2012)

Miller, R.B. (2004). Toward Global Interoperability. Directions Magazine, April 30. [Online] Available: http://www.directionsmag.com/articles/toward-global-interoperability/123759 (July 15, 2012)

Monga, A. (2008). E-government in India: Opportunities and challenges. Journal of Administration \& Governance, 3(2). [Online] Available: http://joaag.com/uploads/5_Monga2EGov3_2_.pdf (July 15, 2012)

Mont, M.C., Bramhall, P., Gittler, M., Pato, J., \& Rees, O. (2002). Identity Management: a Key e-Business Enabler. Hewlett-Packard Laboratories, UK. [Online] Available: http://www.hpl.hp.com/techreports/2002/HPL-2002-164.pdf (August 13, 2012)

Navakouski, M., \& Louis, G. (2012). Interoperability in the e-Government Context. Software Engineering Institute, Carnegie Mellon University. [Online] Available: http://www.sei.cmu.edu/reports/11tn014.pdf (Septermber 3, 2012)

Nordfors, L., Ericson, B., \&Lindell, H. (2006). The Future of eGovernment: Scenarios 2016. VINNOVA - Swedish Governmental Agency for Innovation Systems. [Online] Available: http://www.vinnova.se/upload/EPiStorePDF/vr-06-11.pdf (September 1, 2012)

OECD (2008). Making Life Easy for Citizens and Businesses in Portugal: Administrative Simplification and E-Government. Organisation for Economic Co-Operation and Development [Online] Available: http://www.oecd.org/dataoecd/37/23/42600869.pdf (September 1, 2012)

OECD (2009). Government at a Glance 2009. Organisation for Economic Co-Operation and Development. [Online] Available:

http://www.oecd-ilibrary.org/docserver/download/fulltext/4209151e.pdf?expires=1341518042\&id=id\&accname=gue st\&checksum=7F5931A65265D9C0C63B69986E84D79D (September 3, 2012)

OeE. (2004). e-Government Interoperability Framework, Version 6.0, Office of the e-Envoy (OeE). [Online] Available: http://edina.ac.uk/projects/interoperability/e-gif-v6-0_.pdf (August 1, 2012)

Otenyo, E.E., \& Lind, N.S. (2011). e-Government: The Use of Information and Communication Technologies in Administration. Youngstown, New York: Teneo Press.

Pardo, T.A., \& Burke, G.B. (2008). Government Worth Having: A briefing on interoperability for government leaders, Center for Technology in Government, University at Albany, SUNY. [Online] Available: http://www.ctg.albany.edu/publications/reports/government_worth_having/government_worth_having.pdf (September 1, 2012)

Rabaiah, A., \& Vandijck, E. (2009). A Strategic Framework of E-Government: Generic and Best Practice. Electronic Journal of E-Government, 7(3), 241-258.

Rahav, A. (2012). Citizen Centricity. Icentred blog. [Online] Available: http://www.icentered.com/citizen-centricity (September 1, 2012)

Roussos, G., Peterson, D., \& Patel, U. (2003). Mobile Identity Management: An Enacted View. International Journal of Electronic Commerce, 8, 81-100. 
Safelayer Labs. (2012). Defining an architecture for the complete management of digital identity. [Online] Available: http://labs.safelayer.com/en/research-and-development/focus-areas/iam-30/326-definicion-de-una-arquitectura-para-l a-gestion-integral-de-la-identidad-digital (September 1, 2012)

Seifert, J.W., \& McLoughlin, G.J. (2007). State E-Government Strategies: Identifying Best Practices and Applications. A report prepared for the Congressional Research Service by the Lyndon Baines Johnson School of Public Policy at the University of Texas at Austin. [Online] Available: http://www.fas.org/sgp/crs/secrecy/RL34104.pdf (September 1, 2012)

Sherry, D., Ryan, S.D., Zhang, X., Prybutok, V.R., \& Sharp, J.H. (2012). Leadership and Knowledge Management in an E-Government Environment. Administrative Sciences, 2, 63-81.

Song, H.J. (2006). e-Government in Developing Countries: Lessons Learned from Republic of Korea. United Nations Educational, Scientific and Cultural Organisation (UNESCO). [Online] Available: http://www2.unescobkk.org/elib/publications/083/e-government.pdf (September 1, 2012)

Stoddart, J. (2006). PIPEDA review discussion document: Protecting privacy in an intrusive world. Office of the Privacy Commissioner of Canada, Ottawa.

Suh, S.Y. (2007). Promoting Citizen Participation e-Government: From the Korean Experience in e-Participation. [Online] Available: http://unpan1.un.org/intradoc/groups/public/documents/un/unpan020076.pdf. (September 1, 2012)

Suthrum, P., \& Phillips, J. (2003). Citizen Centricity: eGovernance in Andhra Pradesh. The University of Michigan Business School. [Online] Available: http://www.bus.umich.edu/FacultyResearch/ResearchCenters/ProgramsPartnerships/IT-Champions/eGovernance.pdf (September 1, 2012)

UNPAN. (2010). United Nations EGovernment Global Reports. UN Public Administration Programme. [Online] Available: http://www2.unpan.org/egovkb/global_reports/10report.htm (September 1, 2012)

UNDP. (2007). e-Government Interoperability: Guide. United Nations Development Programme, [Online] Available: http://www.ibm.com/ibm/governmentalprograms/undp-gif-guide.pdf (September 1, 2012)

UNDP. (2007). e-Government Interoperability: Overview, United Nations Development Programme, 2007. Available at http://www.apdip.net/projects/gif/GIFOverview.pdf (September 1, 2012)

United Nations. (2010). United Nations Department of Economic and Social Affairs. United Nations E-Government Survey 2010. UN. [Online] Available: http://www2.unpan.org/egovkb/documents/2010/E_Gov_2010_Complete.pdf. (September 1, 2012)

United Nations. (2012). United Nations E-Government for the People. United Nations Department of Economic and Social Affairs. [Online] Available: http://unpan1.un.org/intradoc/groups/public/documents/un/unpan048065.pdf (September 1, 2012)

West, D.M. (2004). EGovernment and the Transformation of Service Delivery and Citizen Attitudes. Public Administration Review, 64, 1, 15-27.

Wimmer, M.A., \& Tambouris, E. (2002). Online One-Stop Government: A working framework and requirements. In Proceedings of the IFIP World Computer Congress, August 26-30, 2002, Montreal.

Windley, P.J. (2004). Digital Identity: Unmasking Identity Management Architecture. Sebastopol, CA: O'Reilly.

World Bank. (2012). Definition of E-Government, World Bank. [Online] Available: www.worldbank.org/egov (September 3, 2012)

World Economic Forum. (2010). The Lisbon Review 2010: Towards a More Competitive Europe? [Online] Available: http://www3.weforum.org/docs/WEF_LisbonReview_Report_2010.pdf (September 1, 2012)

\section{Notes}

Note 1. Bipartisanship is a political situation, usually in the context of a two-party system, in which opposing political parties find common ground through compromise.

Note 2. In government, bicameralism (Latin bi, two + camera, chamber) is the practice of having two legislative or parliamentary chambers that compromise bills. Bicameralism is an essential and defining feature of the classical notion of mixed government. Bicameral legislatures tend to require a concurrent majority to pass legislation. 
Note 3. In software engineering, a Service-Oriented Architecture (SOA) is a set of principles and methodologies for designing and developing software in the form of interoperable services. SOA design principles are used during the phases of systems development and integration to define how to integrate disparate applications for a Web-based environment and use multiple implementation platforms. SOA is not just an architecture of services seen from a technology perspective, but the policies, practices, and frameworks by which we ensure the right services are provided and consumed.

Note 4. Access and Identity Management (AIM) is a term that describes the management of individual identities, their authentication, authorisation, and privileges/permissions within or across system and enterprise boundaries with the goal of increasing security and productivity while decreasing cost, downtime, and repetitive tasks.

Note 5. The World Economic Forum's study is a biennial review series that assesses the progress made by EU Member countries in the far-reaching goals of the EU's Lisbon Strategy of economic and structural reforms. In addition to assessing the performance of 27 existing EU Members, it also measures the competitive performance of EU candidates and potential candidate countries.

Note 6. In cryptography, certificate authority, or certification authority (CA) is an entity that issues digital certificates. The digital certificate certifies the ownership of a public key by the named subject of the certificate. This allows others (relying parties) to rely upon signatures or assertions made by the private key that corresponds to the public key that is certified. In this model of trust relationships, a CA is a trusted third party that is trusted by both the subject (owner) of the certificate and the party relying upon the certificate. CAs are characteristic of many public key infrastructure (PKI) schemes. Governments worldwide have started owning their own CAs specifically as part of their identity management systems, such national ID card me, electronic passports, etc.

Note 7. GCC is the acronym for Gulf Cooperation Council, also referred to as the Cooperation Council for the Arab States of the Gulf (CCASG). It includes six countries, namely Bahrain, Kuwait, Oman, Qatar, Saudi Arabia, and the United Arab Emirates. The GCC population is estimated to comprise of around 40 million people.

Table 1. e-government maturity models

\begin{tabular}{|c|c|c|}
\hline $\begin{array}{l}\text { Source/ } \\
\text { proponent(s) }\end{array}$ & Phases & Description \\
\hline \multirow[t]{4}{*}{ Chen (2002) } & $\begin{array}{l}\text { Phase 1: } \\
\text { Information }\end{array}$ & $\begin{array}{l}\text { Government “information" is created, categorised, and indexed and delivered to its } \\
\text { citizens through the Internet. }\end{array}$ \\
\hline & $\begin{array}{l}\text { Phase 2: } \\
\text { Communication }\end{array}$ & $\begin{array}{l}\text { E-gov services support two-way ‘communication,’ with citizens communicating } \\
\text { requests through web forms, email, or other Internet media. }\end{array}$ \\
\hline & $\begin{array}{l}\text { Phase 3: } \\
\text { Transaction }\end{array}$ & $\begin{array}{l}\text { "Transaction” services between citizens and governments are supported. Government } \\
\text { branches also use the Internet for transactions among themselves. }\end{array}$ \\
\hline & $\begin{array}{l}\text { Phase 4: } \\
\text { Transformation }\end{array}$ & $\begin{array}{l}\text { An opportunity for the 'transformation' of government practices and services is } \\
\text { exploited. Applications such as e-voting and e-politics that may alter the democratic } \\
\text { and political processes are instituted. }\end{array}$ \\
\hline \multirow{4}{*}{$\begin{array}{l}\text { Chandler \& } \\
\text { Emanuel } \\
(2002)\end{array}$} & $\begin{array}{l}\text { Stage 1: } \\
\text { Information }\end{array}$ & $\begin{array}{l}\text { Government services are delivered online. One-way communication between } \\
\text { government and citizens is put in place. }\end{array}$ \\
\hline & $\begin{array}{l}\text { Stage 2: } \\
\text { Interaction }\end{array}$ & Simple interaction between citizens and governments are supported. \\
\hline & $\begin{array}{l}\text { Stage 3: } \\
\text { Transaction }\end{array}$ & Services enabling transactions between citizens and government are supported. \\
\hline & $\begin{array}{l}\text { Stage 4: } \\
\text { Integration }\end{array}$ & $\begin{array}{l}\text { Integration of services across the agencies and departments of government are put in } \\
\text { place. }\end{array}$ \\
\hline \multirow[t]{3}{*}{$\begin{array}{l}\text { Howard } \\
(2001)\end{array}$} & $\begin{array}{l}\text { Phase 1: } \\
\text { Publish }\end{array}$ & Information about government activities is available online. \\
\hline & $\begin{array}{l}\text { Phase 2: } \\
\text { Interact }\end{array}$ & Enables citizens to have simple interactions through emails with their governments. \\
\hline & $\begin{array}{l}\text { Phase 3: } \\
\text { Transact }\end{array}$ & $\begin{array}{l}\text { Provides citizens with full transaction benefits over the internet with services such as } \\
\text { purchasing licenses and permits. }\end{array}$ \\
\hline West (2004) & Phase 1: & Government websites (usually static at this stage) are used for information display. \\
\hline
\end{tabular}




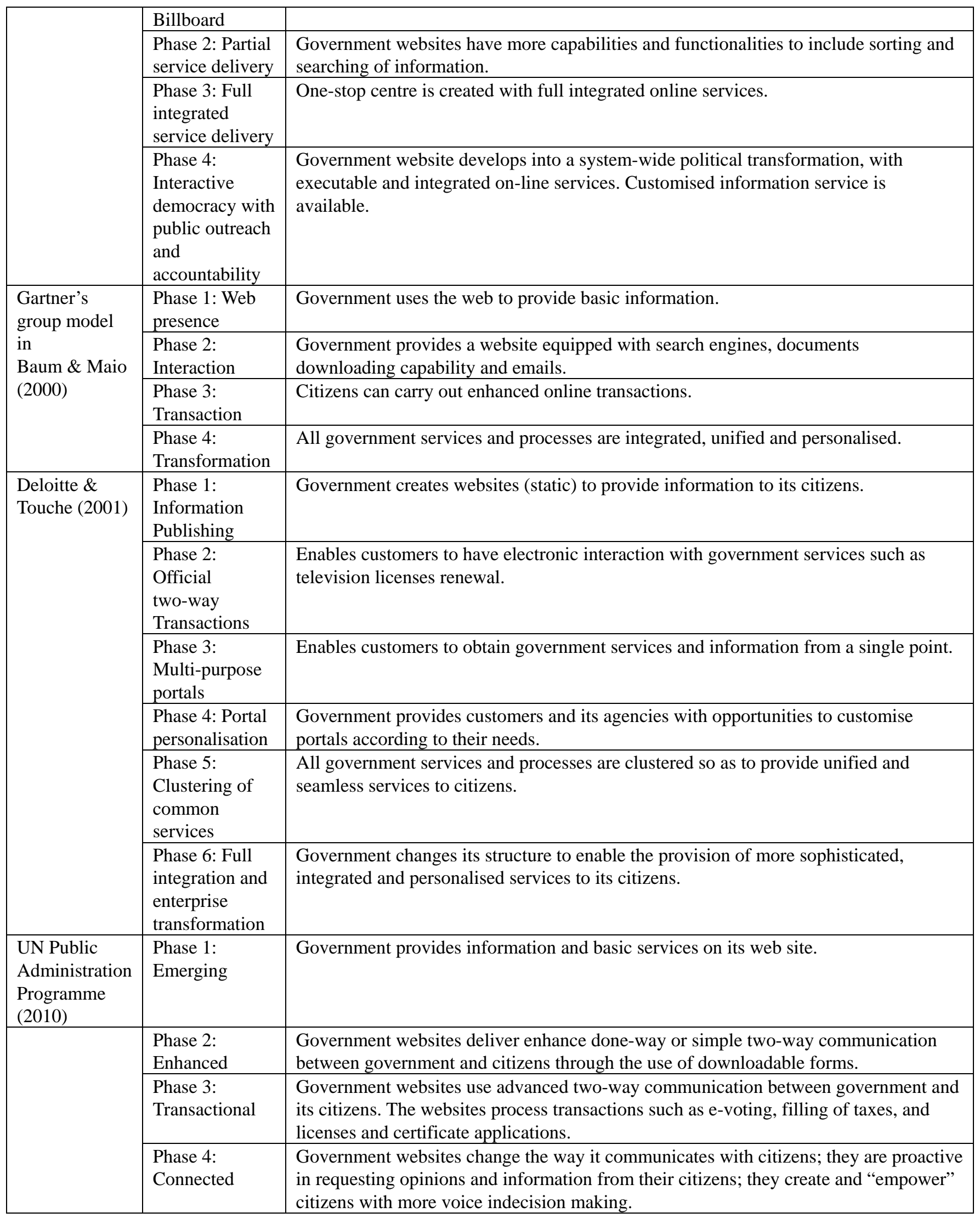

Source: (Ifinedo \& Singh, 2011) 
Table 2. Characteristics of information society

\begin{tabular}{|l|l|}
\hline Characteristics & Description \\
\hline $\begin{array}{l}\text { Information is used as } \\
\text { an economic resource }\end{array}$ & $\begin{array}{l}\text { Organisations make greater use of information to increase their efficiency, to stimulate } \\
\text { innovation and to increase their effectiveness and competitive position, often through } \\
\text { improvements in the quality of the goods and services that they produce. There is also a } \\
\text { trend towards the development of more information-intensive organisations that add } \\
\text { greater amounts of value and thus benefit a country's overall economy. }\end{array}$ \\
\hline $\begin{array}{l}\text { More intensive use of } \\
\text { Information }\end{array}$ & $\begin{array}{l}\text { It is possible to identify greater use of information among the general public. People } \\
\text { use information more intensively in their activities as consumers: to inform their } \\
\text { choices between different products, to explore their entitlements to public services, and } \\
\text { to take greater control over their own lives. They also use information as citizens to } \\
\text { exercise their civil rights and responsibilities. In addition, information systems are } \\
\text { being developed that will greatly extend public access to educational and cultural } \\
\text { provision. }\end{array}$ \\
\hline $\begin{array}{l}\text { Development of an } \\
\text { information sector } \\
\text { within } \\
\text { the economy }\end{array}$ & $\begin{array}{l}\text { The function of the information sector is to satisfy the general demand for information } \\
\text { facilities and services. A significant part of the sector is concerned with the } \\
\text { technological infrastructure, the networks of telecommunications and computers. } \\
\text { Increasingly, however, the necessity is also being recognised to develop the industry } \\
\text { generating the information that flows around the networks: the information-content } \\
\text { providers. In nearly all information societies, this information sector is growing much } \\
\text { faster than the overall economy. The International Telecommunications Union (ITU) } \\
\text { estimates that, in 1994, the global information sector grew by over 5\% while the overall } \\
\text { world economy grew by less than 3\%. }\end{array}$ \\
\hline
\end{tabular}

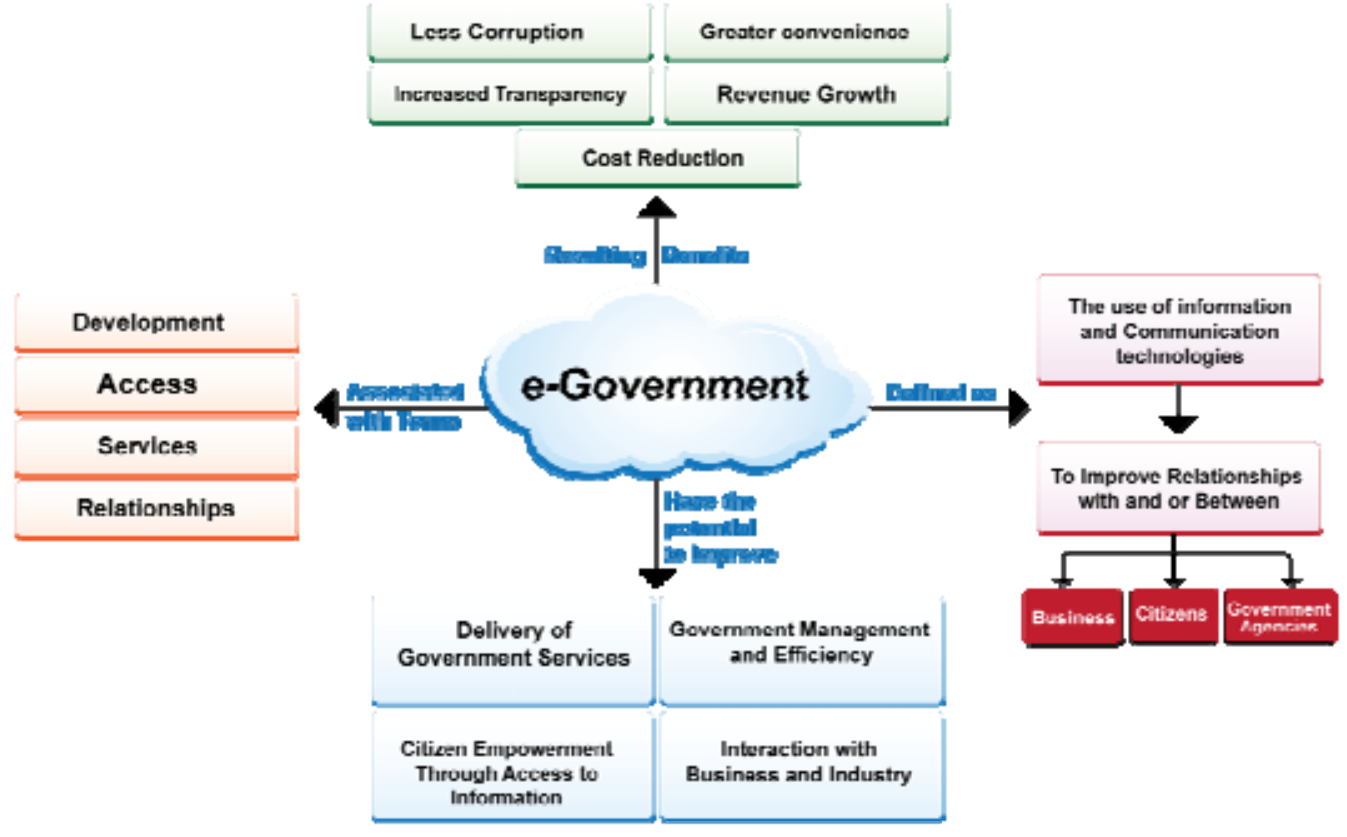

Figure 1. e-government context 


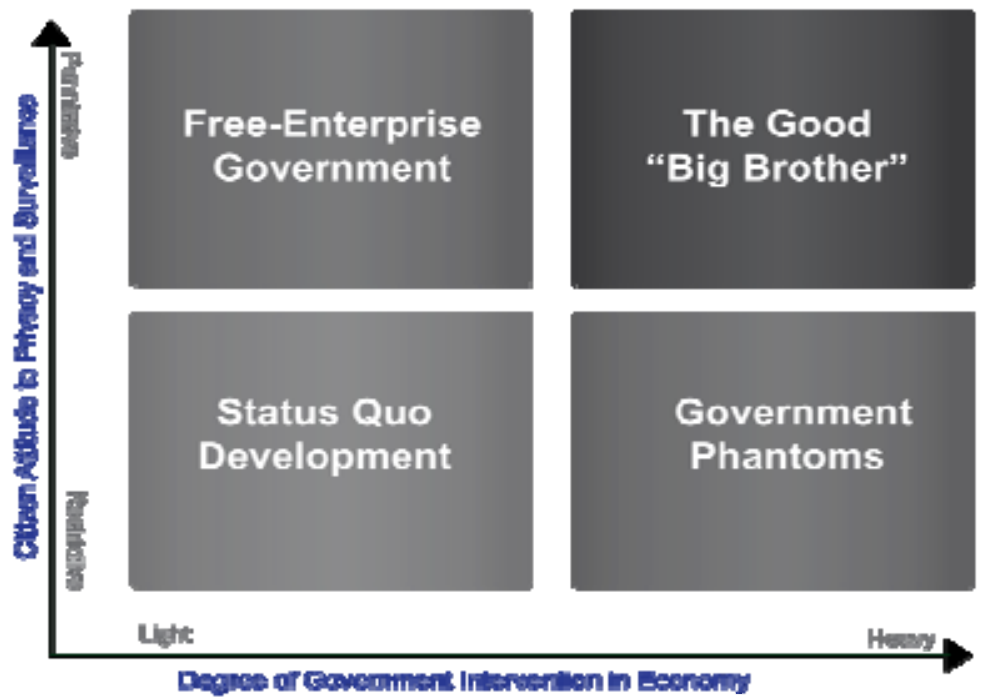

Figure 2. Gartner 2020 government scenarios (Di Maio et al., 2005)

\begin{tabular}{|c|c|c|c|c|}
\hline & \multicolumn{3}{|c|}{ To (destination) } \\
\hline & & G (Government) & B (Business) & C (Citizen) \\
\hline \multirow{3}{*}{$\begin{array}{l}\text { From } \\
\text { (origin) }\end{array}$} & G & Badk ofles converilen & Front ofiles hest & fiont extos hat \\
\hline & B & From afien inpat & Bers & (E-butines) \\
\hline & C & Fram of the het & (E-t) & Eacenth \\
\hline
\end{tabular}

Figure 3. Electronic interactions of e-government (Song, 2006)

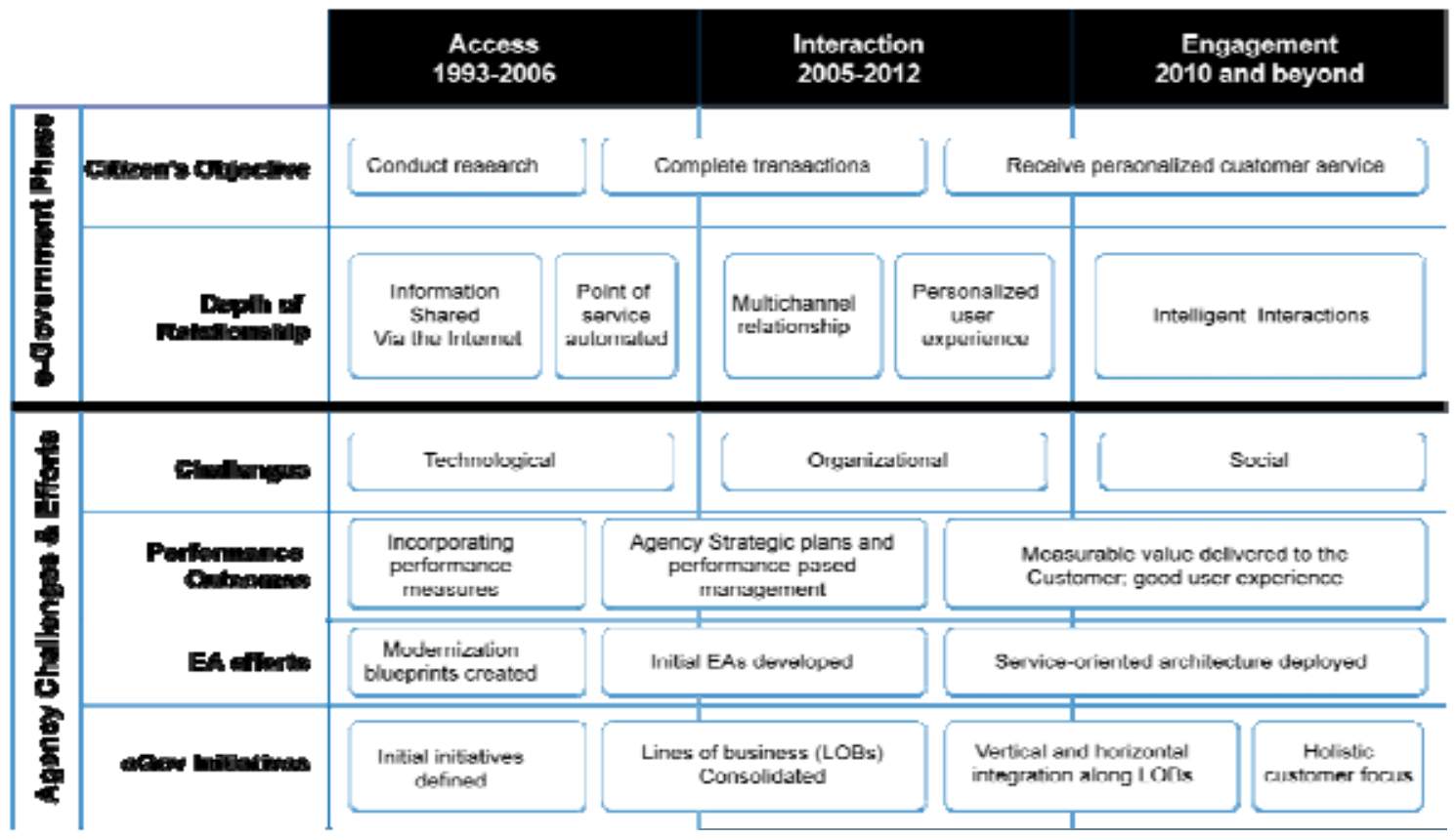

Figure 4. Citizen-centric government phases

Source: Forrester Research, Inc. 


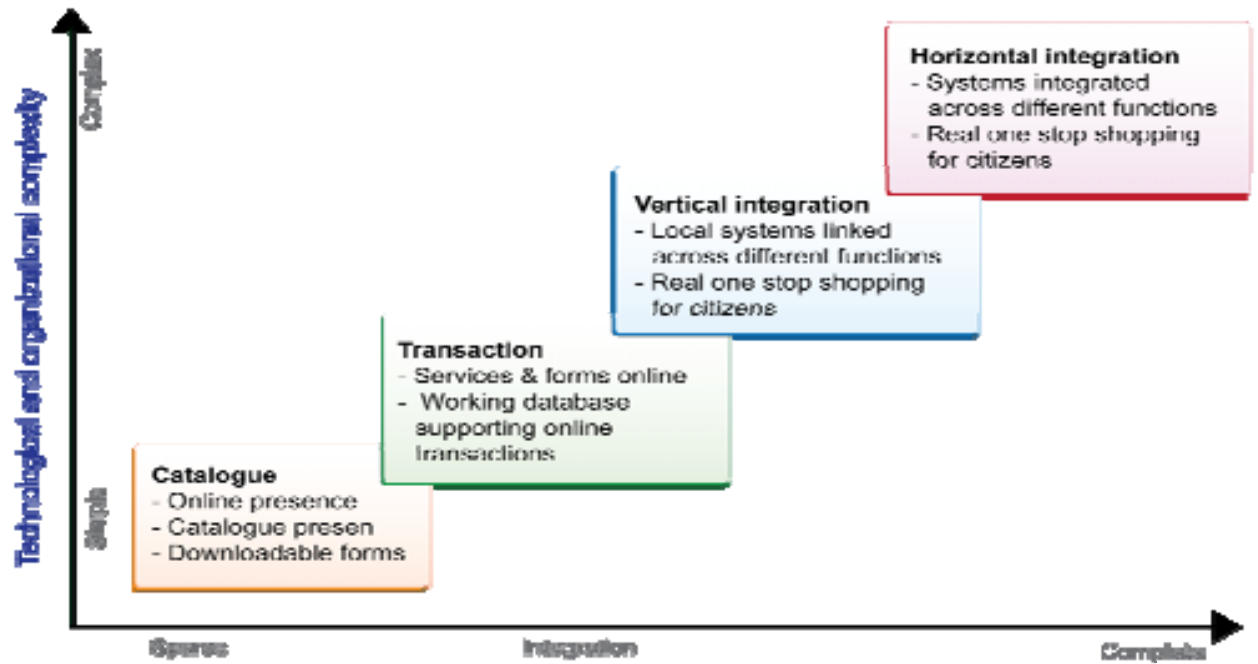

Figure 5. Layne \& Lee's e-government model

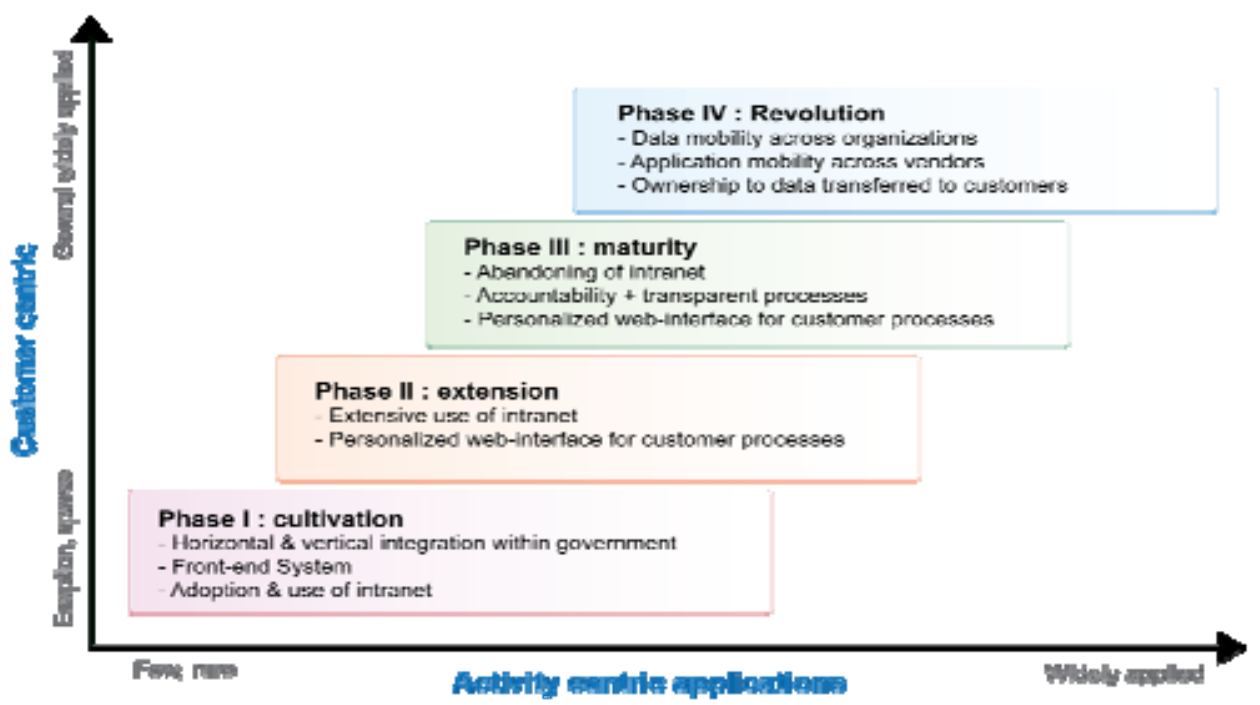

Figure 6 . The customer and activity centric maturity model

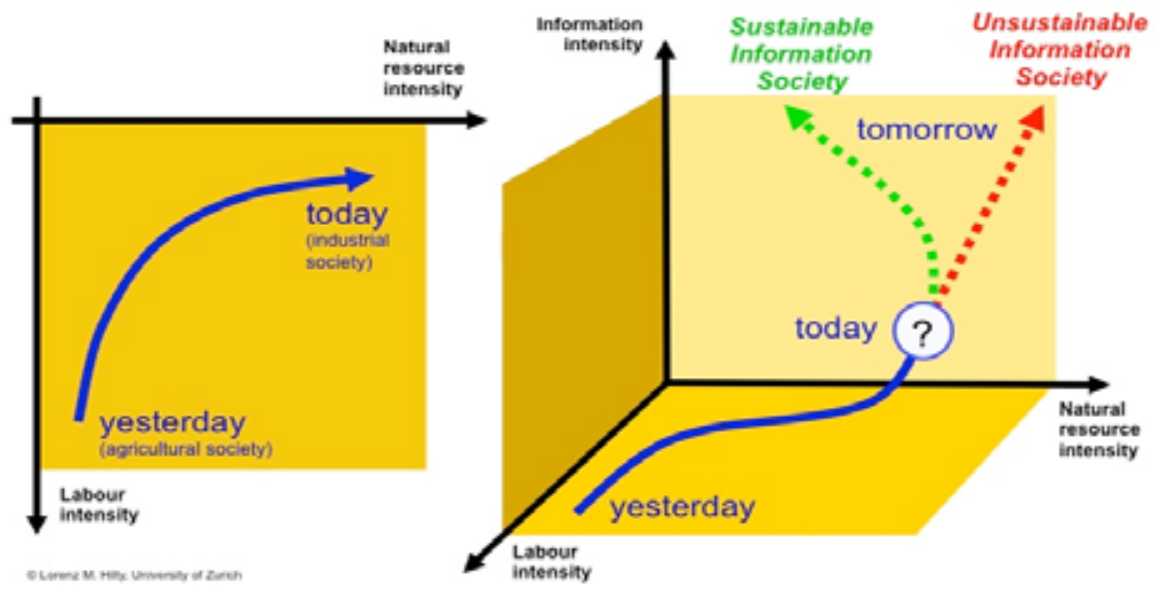

Figure 7. Visions of the information society (Hilty, 2011) 


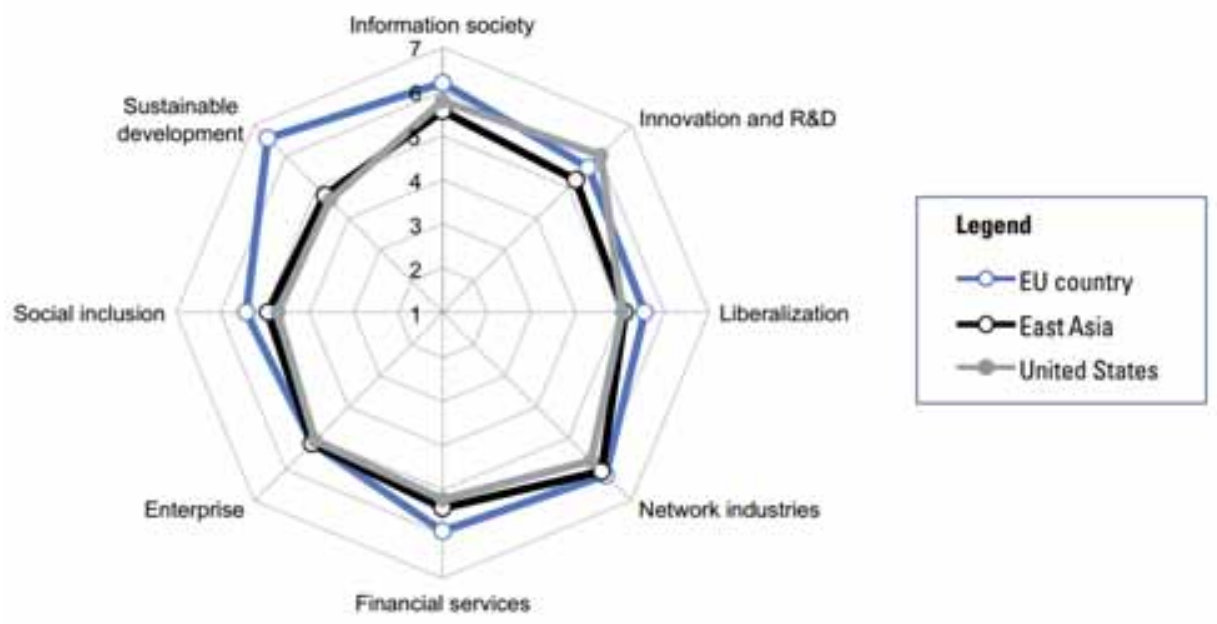

Figure 8. Swedish performance benchmark vis-à-vis the US and East Asia

\begin{tabular}{|c|c|c|c|c|}
\hline \multirow[b]{2}{*}{ Horizontal Layers } & \multicolumn{4}{|c|}{$\begin{array}{l}\text { Vertical Sectors: } \\
\text { main Axis addressed to Government, People, Enterprises and Urban Environment }\end{array}$} \\
\hline & Government & People & Enterprises & Urban Environment \\
\hline Content & ERoumanes & $\begin{array}{l}\text { Community } \\
\text { Development }\end{array}$ & Netrobion of & $\begin{array}{l}\text { Local Environment \& } \\
\text { Sustainable Development }\end{array}$ \\
\hline Applications & 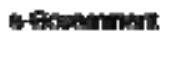 & $\begin{array}{l}\text { c-inclusion for } \\
\text { specific Groups }\end{array}$ & 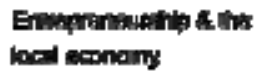 & Culture \& Tourism \\
\hline Generic Services & 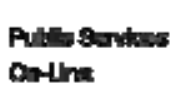 & $\begin{array}{l}\text { Education \& } \\
\text { Training }\end{array}$ & 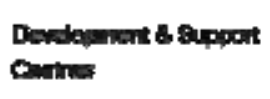 & $\begin{array}{l}\text { GIS, Transport, Land } \\
\text { Management) }\end{array}$ \\
\hline Network & Dpostatestar & $\begin{array}{l}\text { Entertainment \& } \\
\text { Culture } \\
\text { e-Health }\end{array}$ & 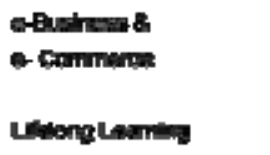 & \\
\hline & Access & Knowledge & Skills & Sustainable Management \\
\hline
\end{tabular}

Figure 9. A framework for co-operation in developing the information society in Europe (digital inclusion and capacity building): an instrument to stimulate debate

Source: Basic Document- Network 13 A Europe Aid Publication (Lozano et al., 2003)

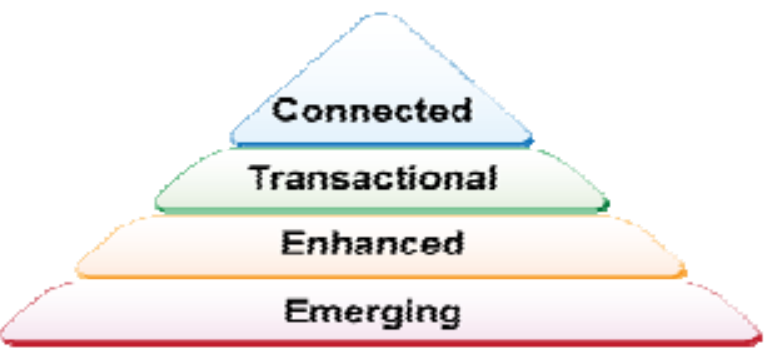

Figure 10. The UN's four stages of online services growth 


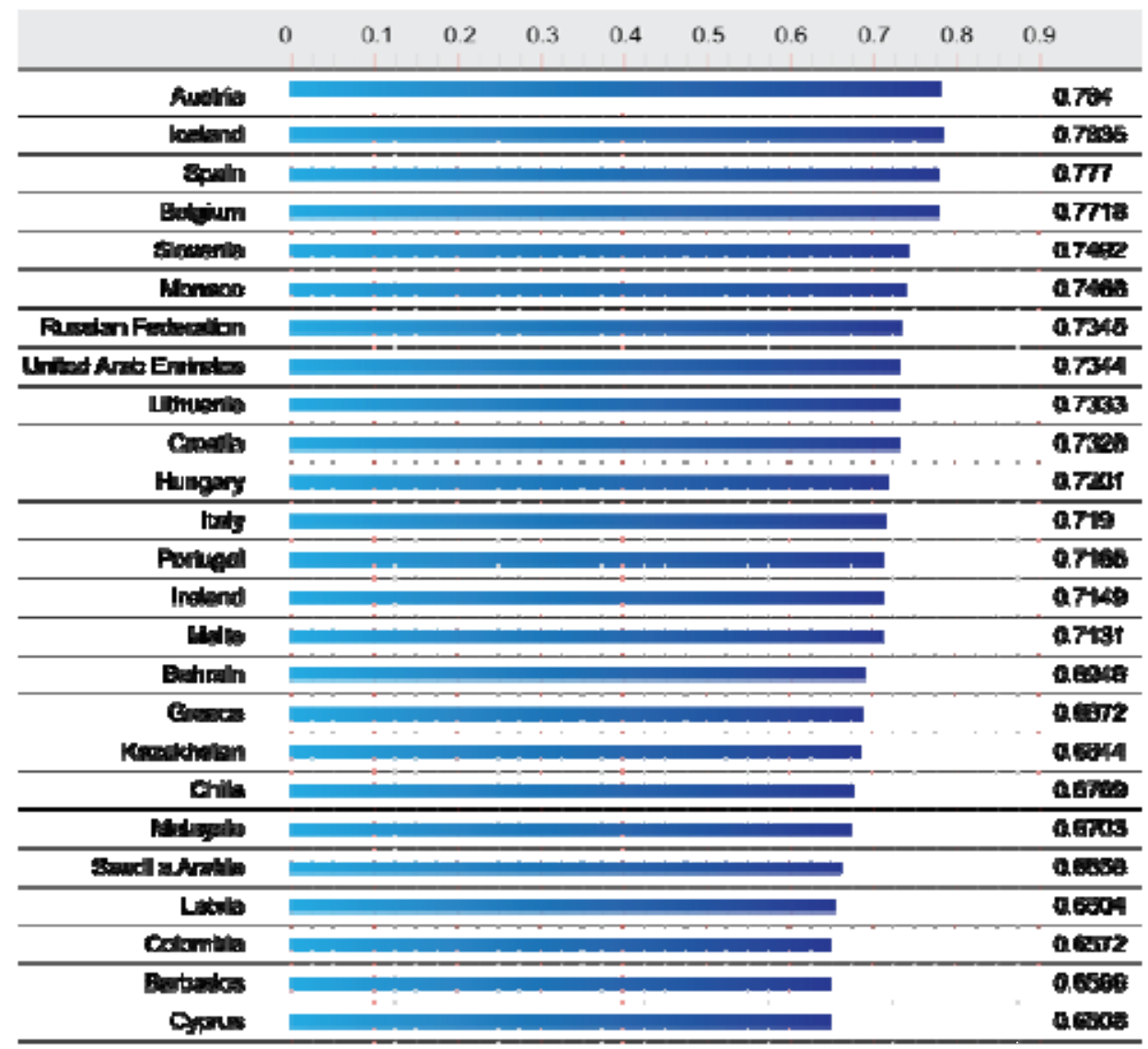

Figure 11. Emerging leaders of e-government development index (United Nations, 2012)

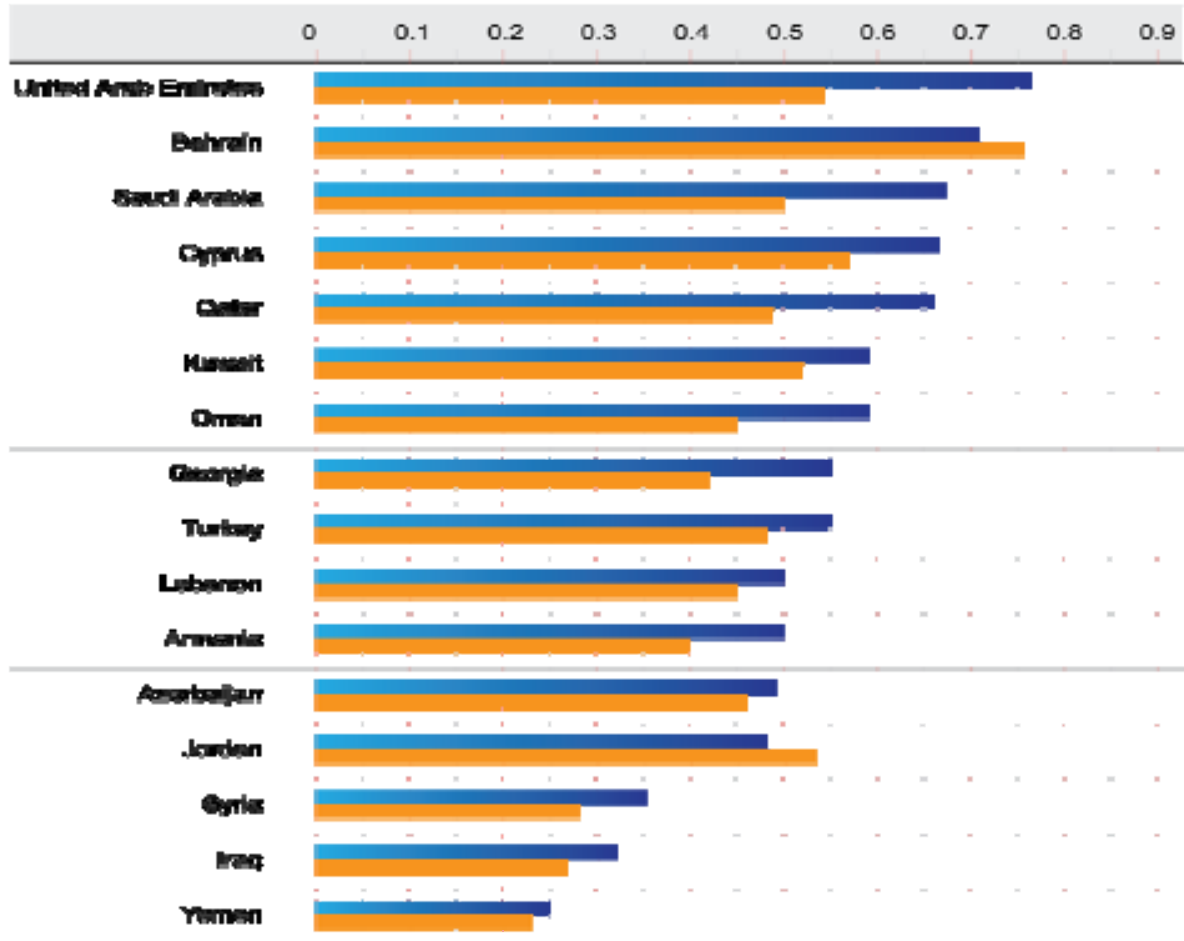

Figure 12. Arab countries e-government development index (United Nations, 2012) 


\begin{tabular}{|c|c|c|c|c|c|c|}
\hline \multirow[b]{2}{*}{ Middle East Region } & \multicolumn{6}{|c|}{ Internet Users in the Middle East and in the world } \\
\hline & $\begin{array}{l}\text { Population } \\
\text { (2011 Est) }\end{array}$ & $\begin{array}{r}\text { Pop.\% } \\
\text { of World }\end{array}$ & $\begin{array}{r}\text { Intormot Usors } \\
31 \text { Des } 2011\end{array}$ & $\begin{array}{l}\text { Population \% } \\
\text { (Penetration) }\end{array}$ & $\begin{array}{l}\text { Usors } \\
\text { \% World }\end{array}$ & $\begin{array}{r}\text { Facobook } \\
31 \text { Des } 2011\end{array}$ \\
\hline Todeldille East & 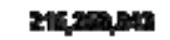 & 2.1. & menes & 256\% & and & 1425yem \\
\hline Restet tha For & sprapen & sats & 2,19apepa & $\mathbf{x a n}$ & $\operatorname{sen}$ & Thespen \\
\hline World Total & $6,930,055,154$ & $100 \%$ & $2,267,233,742$ & $32.7 \%$ & $100 \%$ & $799,092,160$ \\
\hline 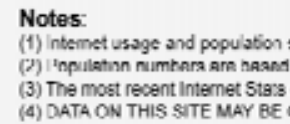 & 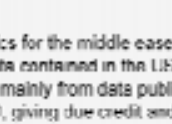 & 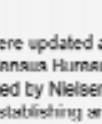 & 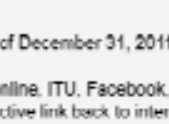 & $\begin{array}{l}\text { outer tusth } \\
\text { cunldsitsts. }\end{array}$ & urces. & \\
\hline
\end{tabular}

Figure 13. Status of communications and service delivery channels in Arab countries

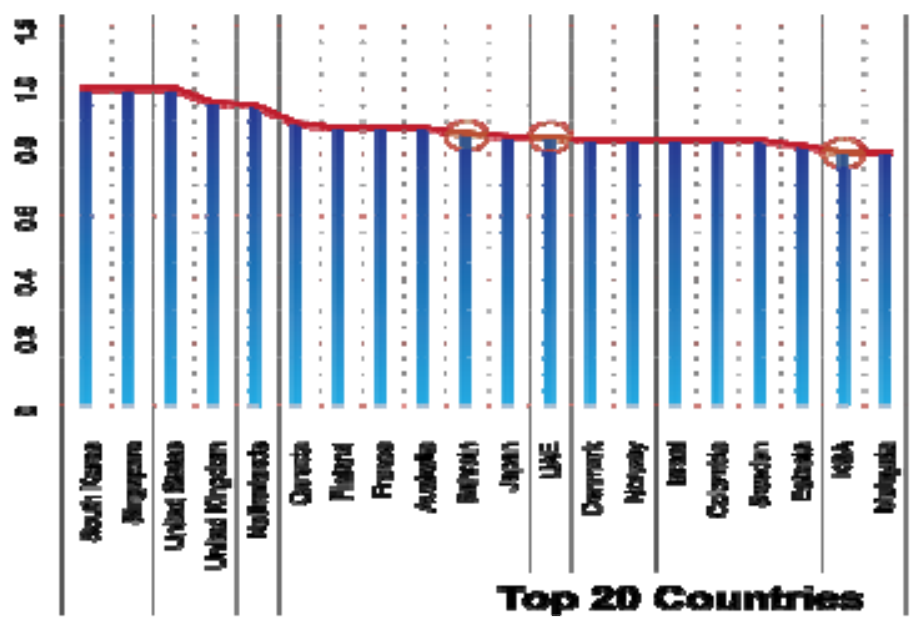

Figure 14. Top 20 countries in online service delivery (United Nations, 2012)

\begin{tabular}{|c|c|c|c|c|c|}
\hline \multicolumn{4}{|c|}{$2010-2011$} & \multicolumn{2}{|c|}{$2009-2010$} \\
\hline Country/Economy & Rank & & Score & Rank & Score \\
\hline Bvodan & 1 & - & ธ.8. & 1 & as \\
\hline Athoapone & 2 & - & 5.50 & 2 & 5.64 \\
\hline Finkend & $\mathbf{a}$ & 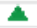 & 5.43 & 6 & 5.4 \\
\hline Andteorland & 4 & - & s.39 & 4 & 8.46 \\
\hline USA & $\mathbf{5}$ & - & 5.30 & 5 & 5.48 \\
\hline Thiven, China & B & $\mathbf{A}$ & 5.9 & 17 & 5.2 \\
\hline Danmedi & 7 & $\nabla$ & 529 & a & 564 \\
\hline Connende & $\mathbf{a}$ & $\nabla$ & 521 & 7 & 6.9.8 \\
\hline Norway & - & $\mathbf{A}$ & 221 & to & 6.22 \\
\hline Somith Konese & 10 & $\overrightarrow{\mathbf{A}}$ & 5.19 & 15 & 5.14 \\
\hline Nethertonds & 11 & $\nabla$ & E. 10 & 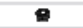 & 5.32 \\
\hline Hong Krong & 12 & $\bar{\nabla}$ & E.19 & $*$ & 630 \\
\hline Germany & 13 & $\mathbf{A}$ & 5.14 & 14 & 5.16 \\
\hline Lubembourp & 14 & $\mathbf{A}$ & a.14 & 17 & $6.0 \mathrm{z}$ \\
\hline $\mathbf{u K}$ & 25 & $\bar{\nabla}$ & 5.t? & 13 & 5.17 \\
\hline lonktand & TE & $\nabla$ & So7 & 12 & 62 \\
\hline Muetrulla & 17 & $\nabla$ & 5.00 & 18 & 5.08 \\
\hline Nom Zoalsand & 18 & $\mathbf{A}$ & 5.03 & 19 & 4.84 \\
\hline lexpen & 19 & 슨 & 4.98 & 21 & 400 \\
\hline Frenca & 20 & $\nabla$ & 4.8F & ขอ & 4.60 \\
\hline Ausotila & 21 & $\nabla$ & 48 & 20 & 4.94 \\
\hline Vertaed & 22 & 슨 & 4.81 & 28 & 4.58 \\
\hline Botolum & 20 & $\nabla$ & 4.8 & 2 & 4.63 \\
\hline UAE & 24 & $\nabla$ & 4.0 & 28 & 465 \\
\hline Ooter & 20 & A & 4.78 & 30 & 4.03 \\
\hline Eseanla & 20 & $\nabla$ & 4.70 & 25 & 461 \\
\hline Motia & 27 & $\nabla$ & $4.7 a$ & 25 & 4.75 \\
\hline Whatrom & 20 & $\nabla$ & 4.74 & 27 & 4.65 \\
\hline Inowend & 28 & $\nabla$ & 4.71 & 24 & Len \\
\hline Buhrein & 30 & $\nabla$ & 4.04 & 2 & 4.00 \\
\hline Cypas & 3 & 스 & 4.5 & $3 x$ & 4.4a \\
\hline Porhyged & 32 & 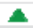 & 45 & 303 & 441 \\
\hline $\operatorname{lCg} A$ & 23 & $\mathbf{A}$ & 4.44 & 38 & 4.3 \\
\hline
\end{tabular}

Figure 15. Source: World economic forum global information technology report 2011 Source: (Dutta \& Bilbao-Osorio, 2012) 


\begin{tabular}{|c|c|c|c|c|c|c|c|c|c|c|c|c|}
\hline \multirow{2}{*}{ Country } & \multirow{2}{*}{$\begin{array}{c}\text { Overall } \\
\text { NRI }\end{array}$} & \multicolumn{3}{|c|}{ Environment } & \multicolumn{3}{|c|}{ Readiness } & \multicolumn{3}{|c|}{ Usage } & \multicolumn{2}{|c|}{ No. Of Tmes in } \\
\hline & & Market & $\begin{array}{l}\text { Political \& } \\
\text { Rogulatory }\end{array}$ & Infrastructure & Individual & Business & Govermment & Individual & Business & Government & TOP 10 & Top 3 \\
\hline Basdar & 1 & 7 & 룰 & $\mathbf{z}$ & - & 2 & 2 & 1 & ฮ & - & $\mathbf{T}$ & 4 \\
\hline Enotione & 2 & 6 & 1 & - & 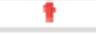 & 6 & 7 & 7 & 10 & $\mathbf{3}$ & 目 & \& \\
\hline Filma & 3 & 6 & 4 & E & 출 & a & id & a & 를 & - & 5 & $\mathrm{~s}$ \\
\hline Eckentant & 4 & $\mathbf{z}$ & 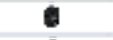 & 5 & - & 中 & - & 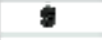 & a & - & $\Delta$ & $\mathbf{s}$ \\
\hline UeA & 5 & - & $\theta$ & 5 & - & ह & - & - & 7 & 4 & 4 & 1 \\
\hline Thast, Chins & 6 & $=$ & $=$ & $=$ & $=$ & $=$ & 5 & $=$ & 1 & 9 & 3 & 2 \\
\hline Danenemb & 7 & - & - & 1 & - & a & - & 5 & - & 6 & 5 & - \\
\hline Bandedy & 8 & 4 & - & 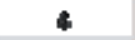 & - & - & - & - & - & a & 4 & - \\
\hline Mnom & 9 & - & a & 8 & - & - & - & 10 & - & - & 4 & - \\
\hline Feres Rap & 10 & - & - & - & - & - & - & 4 & 2 & 1 & $\mathbf{3}$ & 2 \\
\hline Hong Kong en & 12 & 1 & - & - & g & - & $=$ & - & - & 7 & $\mathbf{3}$ & 2 \\
\hline Logharp & 14 & a & 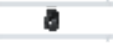 & $=$ & $=$ & $=$ & 7 & 3 & $=$ & $=$ & 4 & 2 \\
\hline labad & 16 & - & - & 1 & 4 & - & - & - & - & - & 3 & 1 \\
\hline Naw Zndat & 18 & - & 9 & - & - & - & - & - & - & - & $\uparrow$ & 1 \\
\hline UеЕ & 24 & - & - & - & 8 & - & 3 & - & - & - & 1 & 1 \\
\hline Com & 25 & 10 & $=$ & $=$ & 10 & $=$ & 훌 & $=$ & $=$ & $=$ & 3 & 1 \\
\hline
\end{tabular}

Figure 16. Development indexes of countries in the global information technology report 2011 Source: (Dutta \& Bilbao-Osorio, 2012)

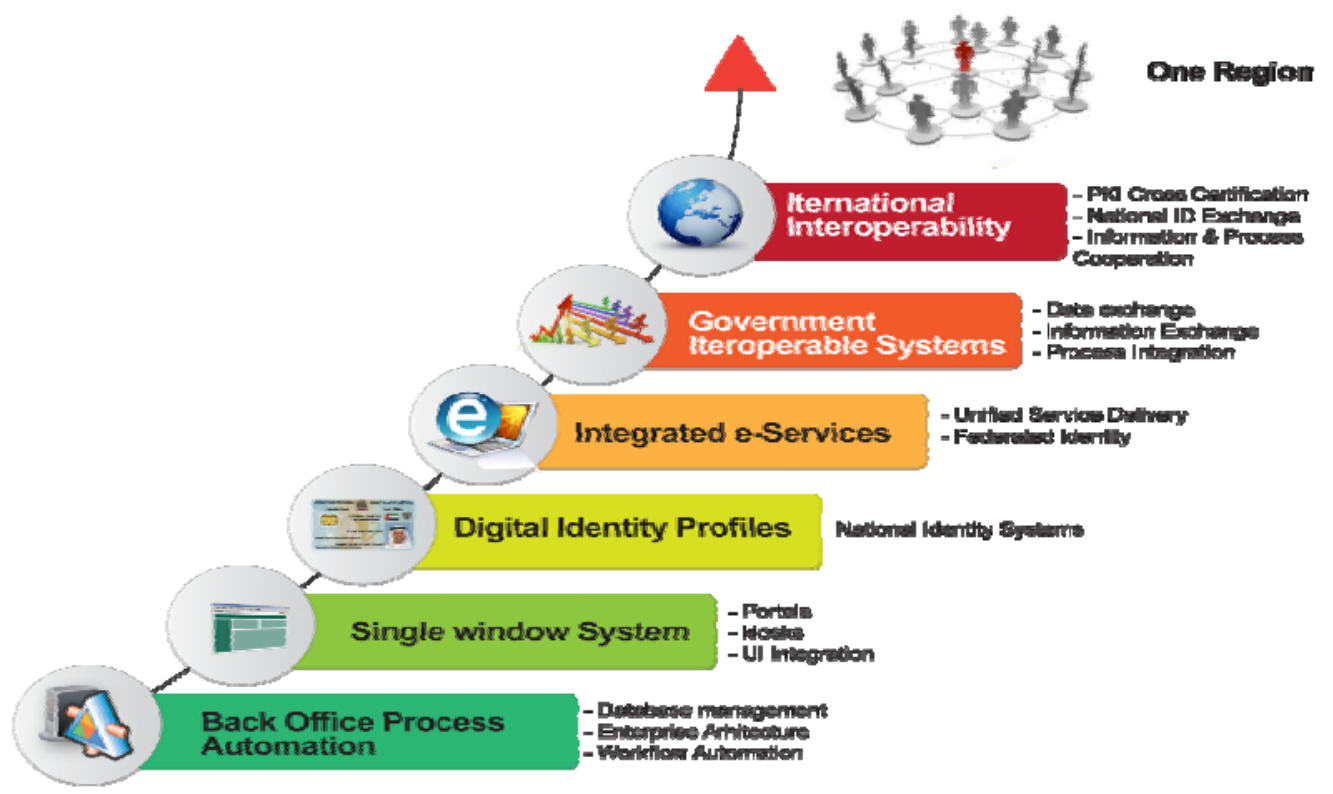

Figure 17. A six staged e-government roadmap 


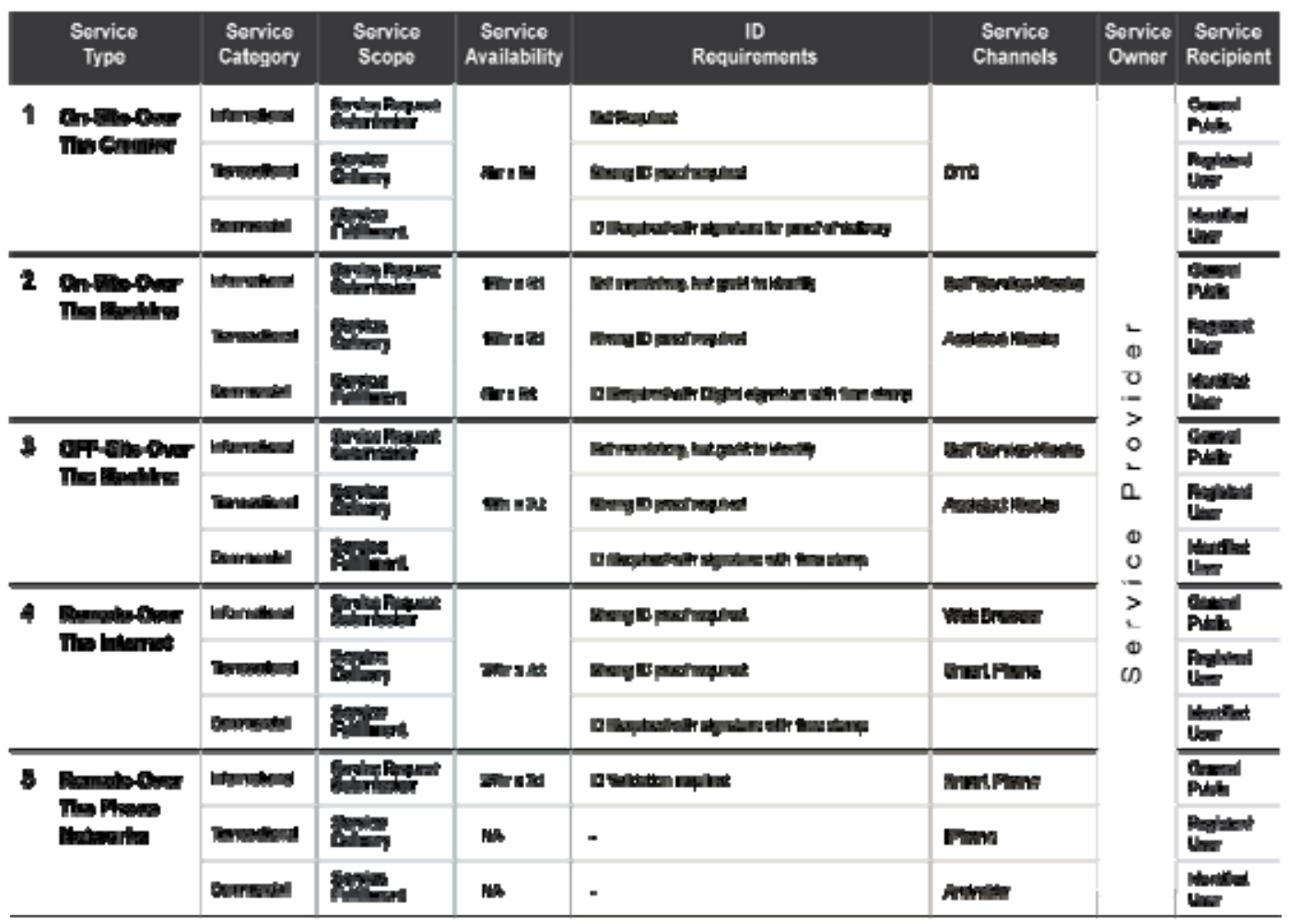

Figure 18. Service types and channels

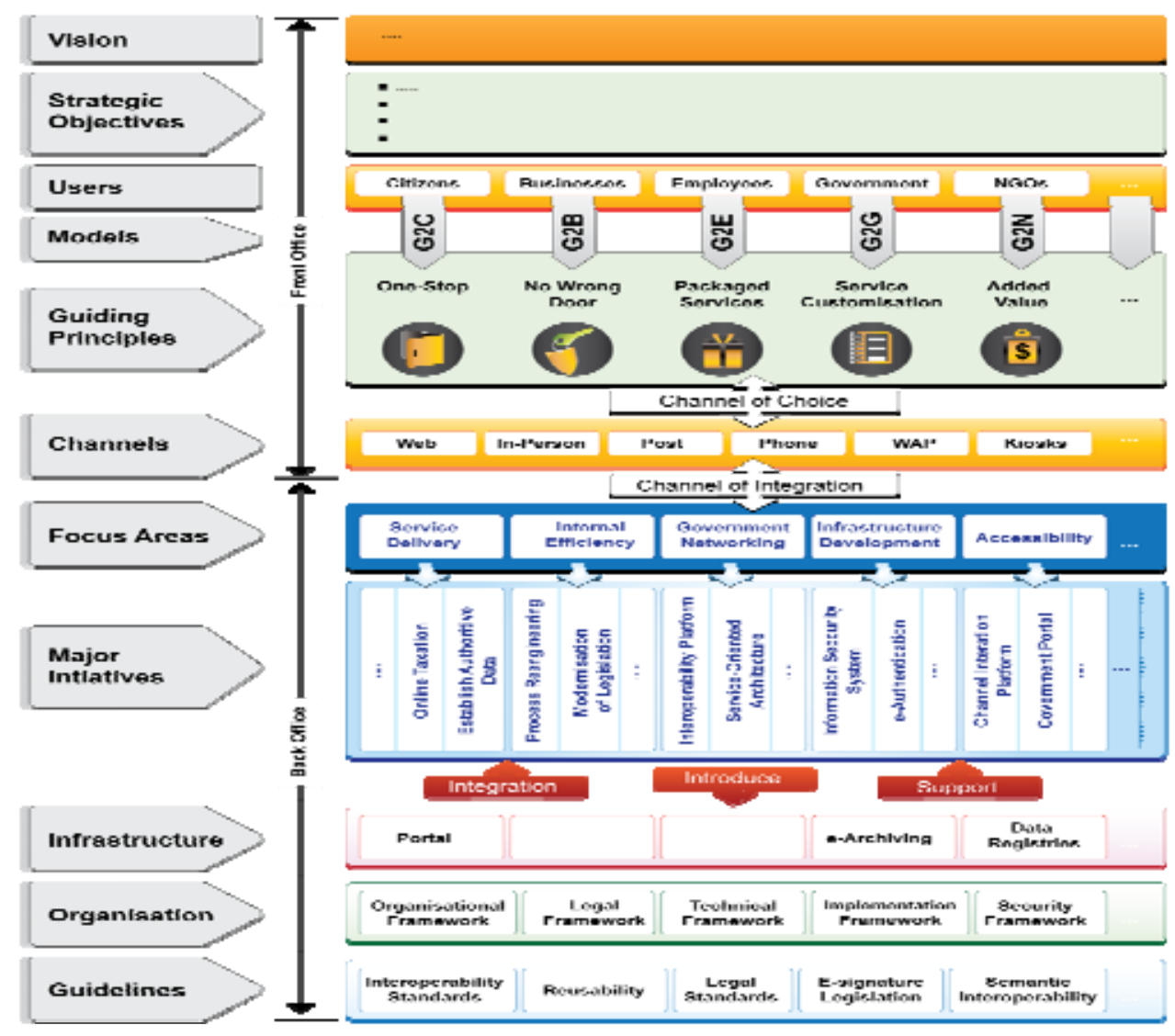

Figure 19. Strategic framework for e-government development (Rabaiah \& Vandijck, 2009) 


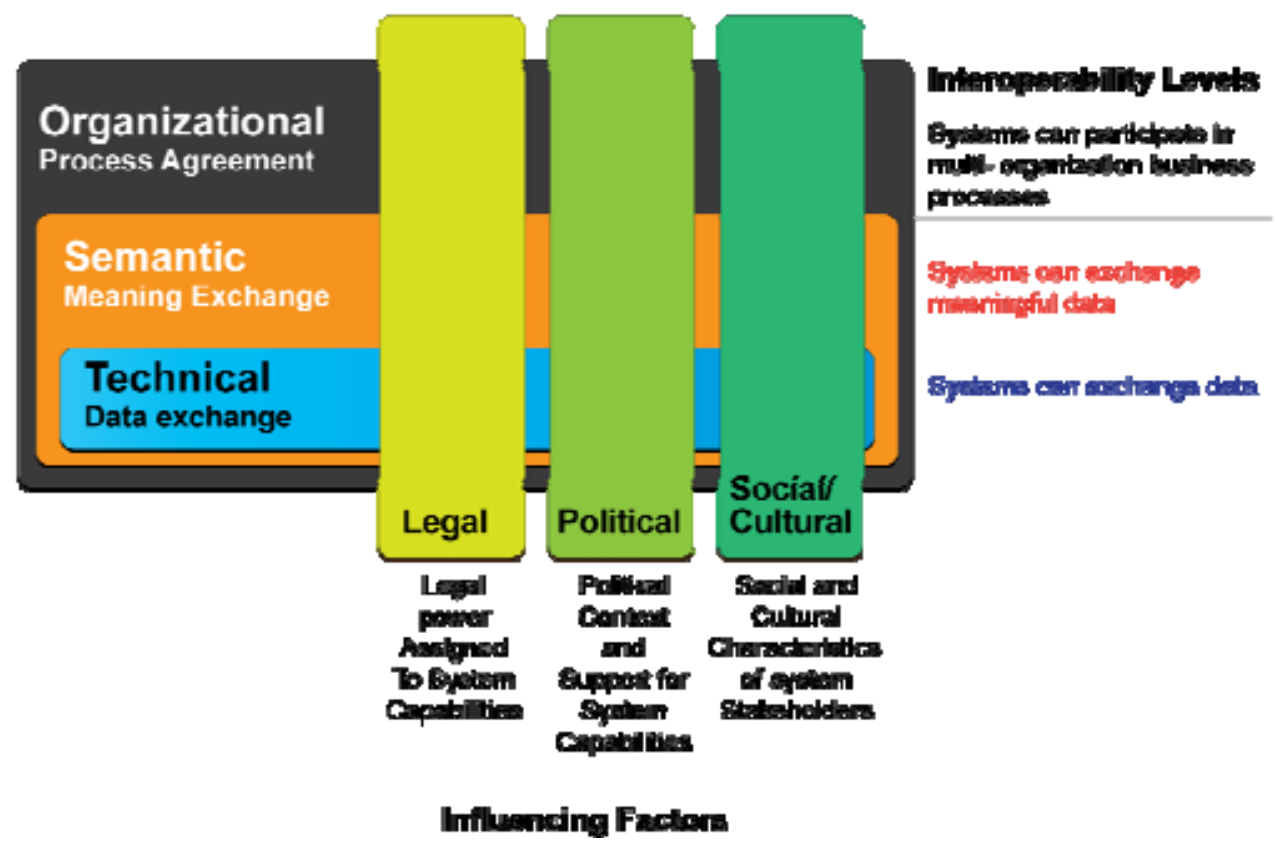

Figure 20. E-government interoperability model

Cooperating partners with compatible visions, aligned priorities, and focused objectives

Aligned legislation so that exchanged data is accorded proper legal weight
Political Context

Legal Interoperability

Legislative Alignment

Coordinated processes in which different organisations achieve a previously agreed and mutually beneficial goal

Organisational Interoperability Organisational and Process Alignment

Precise meaning of exchanged information Which is preserved and understood by all parties

Semantic Interoperability

Semantic Alignment

Technical Interoperability

Planning of technical issues involved in linking computer systems and services

Interaction and Transport

Figure 21. European interoperability framework levels (European Commission, 2004) 